\title{
Article \\ Adaptative Cover to Achieve Thermal Comfort in Open Spaces of Buildings: Experimental Assessment and Modelling
}

\author{
MCarmen Guerrero Delgado ${ }^{1}$, Daniel Castro Medina ${ }^{1}{ }^{\mathbb{D}}$, Jose Sánchez Ramos ${ }^{1}{ }^{\circledR}$, Teresa Rocío Palomo Amores ${ }^{1}$, \\ Servando Álvarez Domínguez ${ }^{1}$ and José Antonio Tenorio Ríos ${ }^{2, *}$ (i) \\ 1 Grupo Termotecnia, Escuela Técnica Superior de Ingeniería, Universidad de Sevilla, Camino de los \\ Descubrimientos S/N, 41092 Seville, Spain; mgdelgado@us.es (M.G.D.); dcastro@us.es (D.C.M.); \\ jsr@us.es (J.S.R.); tpalomo@us.es (T.R.P.A.); salvarez@us.es (S.Á.D.) \\ 2 Spanish National Research Council (CSIC), 28033 Madrid, Spain \\ * Correspondence: tenorio@ietcc.csic.es; Tel.: +34-913-020440
}

\section{check for} updates

Citation: Guerrero Delgado, M.; Castro Medina, D.; Sánchez Ramos, J.; Palomo Amores, T.R.; Álvarez Domínguez, S.; Tenorio Ríos, J.A. Adaptative Cover to Achieve Thermal Comfort in Open Spaces of Buildings: Experimental Assessment and Modelling. Appl. Sci. 2021, 11, 7998. https://doi.org/10.3390/app11177998

Academic Editor: Constantinos A. Balaras

Received: 7 August 2021

Accepted: 27 August 2021

Published: 29 August 2021

Publisher's Note: MDPI stays neutral with regard to jurisdictional claims in published maps and institutional affiliations.

Copyright: (C) 2021 by the authors. Licensee MDPI, Basel, Switzerland. This article is an open access article distributed under the terms and conditions of the Creative Commons Attribution (CC BY) license (https:// creativecommons.org/licenses/by/ $4.0 /)$.
Abstract: The global need for healthy and safe open spaces faces continuous temperature rise due to the heat island phenomenon and climate change. This problem requires new strategies for improving the habitability of open spaces (indoor and outdoor conditions in buildings). These techniques include reducing solar radiation, reducing the temperature of surrounding surfaces, and reducing the air temperature. The radiant solutions are essential for outdoor comfort, both in summer and in winter. They are easy to integrate into open spaces. This study explores a new concept of radiant solutions adapted for outdoor spaces. The solution was evaluated in a test cell to obtain its thermal behaviour in different operation conditions. Solutions were optimised for operating in a cooling regimen since it has been identified that the demands for comfort in open spaces in hot climates during the most severe summer months are more pronounced. Experimental results have allowed getting an inverse model to analyse the thermal behaviour of the solution. The inverse model achieved high precision in its estimations. Also, it facilitated knowing the radiant and convective effects. Only the radiant heat flux is relevant in open spaces with a low level of air confinement. Finally, the discussion describes the application of the proposed model. The model allows the replicability of the solution-creating new designs (integration) or evaluating into different operating conditions of the system. This discussion demonstrates the high level of knowledge acquired in the characterisation of the solution studied.

Keywords: thermal comfort; radiant system; open spaces; thermal adaptation

\section{Introduction \\ 1.1. Context}

Street life is facing the challenge of the continued rise in temperatures due to the heat island phenomenon combined with climate change. Extreme temperatures make it impossible to use outdoor spaces and open urban buildings for long periods in summer, as they become heat traps. Citizens need these open environments to be comfortable in a sustainable way [1]. Both phenomena have consequences for health, economic development, employment, and urban planning, among other aspects [2]. In many regions of the Mediterranean climate, increasing temperatures and drought are already a reality. Climate data show that, during the central hours of the day, thermal conditions are not favourable for the use of open spaces unless actions are taken so that such situations are smoothed. In this context, we must adapt to new solutions to improve the microclimate and lifestyle in cities.

\subsection{Main Considerations of Thermal Comfort in Open Spaces}

Creating a comfortable thermal environment in urban open spaces requires a good understanding of human thermal comfort outdoors. Höppe [3] proved in his work that 
indoor comfort indicators are not valid for outdoor use. He even discussed the need for more detailed dynamic models than in the interior due to the spatial and temporal variability of the excitations (air movement, solar radiation, or radiant exchanges with neighbouring surfaces).

Numerous studies have been developed for analysing comfort/discomfort in open spaces, outdoor spaces, or semi-outdoor spaces. From the point of view of urban thermal comfort, the study of how an external environment may or may not generate thermal comfort conditions necessarily requires understanding how the human body exchanges energy with its immediate environment [4]. The energy exchange depends on a series of factors and parameters, the former refers to the characteristics of the people, and the latter are related to the microclimate of the urban environment where these people are located. Pinto et al. [5] demonstrated the difficulty of evaluating comfort in open spaces and the invalidity of conventional methods tested indoors. These authors proposed an alternative method that has been validated with a sample of more than 500 people. On that line, authors such as Sarhadi et al. [6] evaluated the importance of the direct and indirect effects of environmental and climatic factors on the thermal comfort of people as the primary users of these spaces. The study that they carried out determined that air temperature, wind speed, thermal radiation, and relative humidity are the variables that have the most significant impact on outdoor thermal comfort. Liu et al. [7] analysed the effects of the microclimate parameters on the thermal sensation in different seasons of the year. The air temperature was the factor with the most significant influence on thermal comfort, but air temperature's relative contribution to wind chill gradually decreased, changing the season from spring to winter. However, for thermal radiation, the trend of the contribution to wind chill was reversed. Likewise, Lai et al. [8] corroborated the four variables mentioned above and determined that the variable with the most significant impact is the outside temperature, followed by the incident thermal radiation.

Furthermore, they concluded that incident thermal radiation has a more significant impact on outdoor thermal comfort than wind speed, which is a factor that does not occur indoors. Wang et al. [9] analysed the influence of air velocity and temperature on comfort and added the length of stay. The time dependence was an actual result that should be taken into account in outdoor applications. Zhang et al. [10] studied the effects on thermal comfort in a semi-open transition space. They analysed and determined that, when walking, the disturbance due to wind speed significantly impacted the thermal sensation, since the transfer of heat by convection on the skin's surface was improved. However, they highlighted the importance of controlling the radiant heat exchange in transition spaces to achieve thermal comfort.

In conclusion, treatment indoors and outdoors is different. Achieving an acceptable level of long-term comfort outdoors is more difficult in summer than in winter. In addition to shading and reducing the entry of outside air, it is necessary to create cool surfaces to reduce radiation heating. From the literature review, radiant heat is one of the most representative heat fluxes in the energy balance in the skin or clothes. This argument is one of the foundations of this work. Radiant solutions for interiors have been studied without breaking down the radiant and convective effects. The radiant effect is desired and sought after in the conditioning of outdoor spaces. The review about thermal comfort in open spaces showed the most relevant key performance indicators for climatic comfort in open spaces. They all showed that the required thermal treatment for climatic control in open spaces depends on the final use of space. In open spaces, it is not intended to achieve thermo-hygrometric conditions such that visitors can experience a feeling of wellbeing comparable to that found in heated indoor areas [11]. Also, thermal radiation has a role more significant than $40 \%$ when the duration of the stay is less than one hour [12] Specifically, recent studies proved that surface cooling has a high impact on the comfort of open spaces [13]. However, authors like Rocha et al. [14] designed a complete example of an intervention in a semi-open space, which showed a possible but complex challenge. Achieving this challenge requires improving existing solutions, for example, comfort 
models [5], simulation tools (BIMtoBEM) [14], and natural techniques, to avoid an excess of energy consumption.

\subsection{Bioclimatic Techniques}

Climatic control of open spaces requires new strategies or techniques for improving their habitability. These techniques contemplate reducing solar radiation, the temperature of the surrounding surfaces, and the air temperature.

The effective blocking of solar radiation is the most effective measure, to such an extent that there is practically no interest in implementing any technique without eliminating the radiant exchange by a significant percentage. The immediate solution to blocking radiation is the integration of vegetation. Vegetation effectively reduces thermal radiation in urban open spaces. Many studies have quantified the reduction in mean radiant temperature under trees. For example, Wang et al. [15] showed that the mean radiant temperature in a grove was 7.4 K lower than in an open space, on average. Also, Yupeng et al. [16] showed that a $10 \%$ increase in the coverage of urban vegetation could reduce the mean radiant temperature by up to $8.3 \mathrm{~K}$ in general.

In addition to using vegetation, either trees or plant covers, another possible solution is artificial covertures, whose objective is to block solar radiation. Hassan Abdallah et al. [17] evaluated different shading strategies that integrated, in addition to vegetation, the installation of artificial covers to improve the thermal sensation in the open spaces of the students of the Faculty of Engineering of the University of Egypt. The study results showed that their integration caused a reduction in the average radiant temperature of $7 \mathrm{~K}$. The use of artificial covers also presents the need to study the materials used to reduce the high absorption of solar radiation. In this line, Rossi et al. [18] investigated different textile materials in terms of the sensation of external thermal comfort of pedestrians in summer for their integration in solar awnings. The results showed how the integration of low-emissivity infrared textiles in the lower layer of the ceilings achieved an average daily reduction of PET (physiological equivalent temperature) of up to $2.5 \mathrm{~K}$. Finally, the studies of highly reflective materials and their integration in urban architecture to mitigate the heat island and improve the habitability of spaces have been studied $[19,20]$.

In addition to shading strategies, it is necessary to reduce the temperatures of the surrounding surfaces, as previously commented. In this line, the vegetation also plays a fundamental role. It is essential to block short-wave radiation (solar control solutions). However, this type of solution absorbs part of this radiation and increases its surface temperature. So, it is a significant challenge to develop solar control solutions with low temperatures (under air temperature). This effect is not the same as talking about cold material at temperatures higher than the surrounding air. That is why researchers speak of vegetation as a proper surface treatment. Many authors have studied the influence of vegetation on the decrease in surface temperature. For example, Bibanco et al. [21] measured a vertical plant surface and obtained that its maximum temperature was $24 \mathrm{~K}$ lower than a reference wall. In addition to vegetation, high reflectance surfaces also have lower surface temperatures than a conventional surface treatment. The decrease in surface temperature on high-albedo surfaces has been analysed in various studies. For example, Dionysia et al. [22] investigated the application of cold materials on ceilings and pavements. The study results showed that the surface temperature was reduced by $10 \mathrm{~K}$ compared to the conventional situation.

Finally, and in general, the temperature reduction was achieved by driving cold air into the space to be conditioned, where the air was cooled through environmental heat sinks [23] and therefore had a higher temperature than cold air used in conventional building conditioning. The use of a natural sink for air cooling is possible with known techniques such as evaporative cooling [24] and innovative systems such as the "falling-film system" [25]. 


\subsection{Active Surfaces (Cooling and Heating Ceiling Pannel)}

Radiant exchange, as previously mentioned, is significant in terms of thermal comfort in spaces (both indoors and outdoors) [26,27]. For this reason, many researchers have studied radiant solutions as a conditioning system since they can be considered among the technologies capable of meeting the requirements of sustainable heating and cooling [28]. Recently there has even been a boom of publications on experimental characterisation for the correct operation of this type of solution inside buildings [29-31], none of them applied in open spaces.

It is possible to find a high diversity of studies about radiant solutions in the existing literature. For example, Shen et al. [32] studied a conventional system of tubes embedded in a wall, through which cooled water circulated naturally, in this case through the use of evaporative cooling. Radwan et al. [33] proposed a new multi-segmented ceiling radiant panel. The study results showed that the new panel can achieve a high temperature uniformity and a greater cooling capacity of approximately 51\% more. Serageldin et al. [34] also proposed a new radiant roof system with segmented concave surfaces. For the same conditions, the proposed system reduces the average air temperature by $2 \mathrm{~K}$. For all existing radiant solutions, a characterisation is required that allows efficient control of the system and operation, considering convective and radiant effects separately [28].

The review highlights that radiant solutions have been used and studied extensively and integrated into the interiors of buildings [35]. However, there is no integrated or proposed radiant solution for open-space conditioning.

\subsection{Aims and Originality}

The global need for open spaces that are healthy and safe faces the problem of continually rising temperatures due to the heat island phenomenon and climate change. Therefore, it promotes the development of new solutions that improve the microclimate and life in cities. As previously mentioned, the climatic control of an open space requires implementing different strategies to improve its habitability. These techniques contemplate the reduction of solar radiation, the surrounding surfaces' temperatures, and air temperature. In this line, radiant systems are interesting as they function by blocking solar radiation and simultaneously generating cold surfaces.

The literature review has evidenced some apparent knowledge gaps when it is necessary to know the thermal behaviour of a radiant solution in order for it to be adapted for use in open spaces (for example, radiant vs. convective effects). These knowledge gaps can be filled by characterising a new concept of radiant solution adapted for outdoor spaces by an empirical model obtained through real measurements. The aim of this study was to develop a replicable methodology that would allow the integration of this solution into open spaces. This conceptual solution is made up of conventional elements integrated into a design adapted to this type of space. In this study, the proposed conceptual solution is described and experimentation has been carried out to evaluate its behaviour under different design and operation conditions. Besides, as previously commented, thermal characterisation is required to control the system and for operation after its integration. Therefore, the developed model allows users to estimate the thermal behaviour of the solution under any operating conditions and to know the radiant and convective effect. Only the radiant effect is efficient in open spaces. This characterisation is carried out from the results obtained in the solution experimentation campaign.

Importantly, this work emphasises the summer regime. Hence, the solution is optimised for operation in cooling conditions. These will be the prevailing working conditions (a more significant number of hours of operation). However, it has been characterised in heating mode to increase the number of working hours.

The method followed in this work to characterise the solution can be summarised in four steps to achieve the proposed objective. The first step is designing the radiant element and assembling a coherent experimental prototype to analyse the solution's performance. In the second step, the solution is modelled as a heat exchanger embedded in a construction 
element. Steps 1 and 2 are faced in parallel, feeding steps 2 to 1 for the definition of monitoring and the experimental plan. Once the different experiments are completed, the solution is characterised in steps 3. In these steps, the parameters of the model are identified and experimentally validated. Finally, step 4 synthesises and discusses the knowledge acquired by several indicators that allow its evaluation, both in operation and in the design phase.

\section{Materials: System Description and Experimental Set-Up}

\subsection{System}

The radiant solution of this study is a modular solution, which facilitates the coupling of successive modules in parallel (Figure 1a). A module consists of machine-made meanders made from multilayer composite piping placed on a metal structure attached to the ceiling. Figure 1 shows the dimensions of $1.6 \mathrm{~m}$ in length and $0.33 \mathrm{~m}$ in width of each module of the tested solution (Figure 1a). The blue arrow indicates the fluid inlet to the module, coming from the accumulation volume or another previously coupled module. The section represented (Section A-A, shown in Figure 1b) indicates the number of steps the tube has for a module, 10 steps, and the configuration adopted for the experiments carried out. The linear length of a module is approximately $18 \mathrm{~m}$ with an outside diameter of $16 \mathrm{~mm}$ and $2 \mathrm{~mm}$ thick.

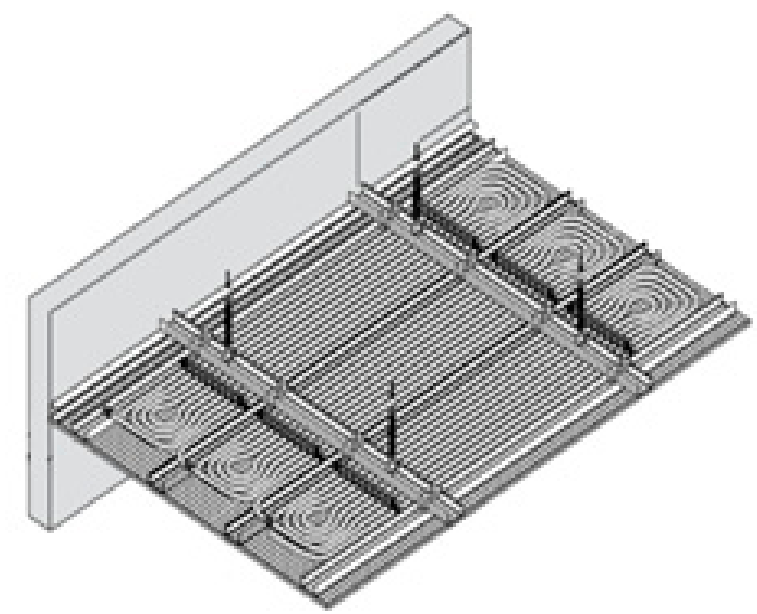

(a) Three module coupling

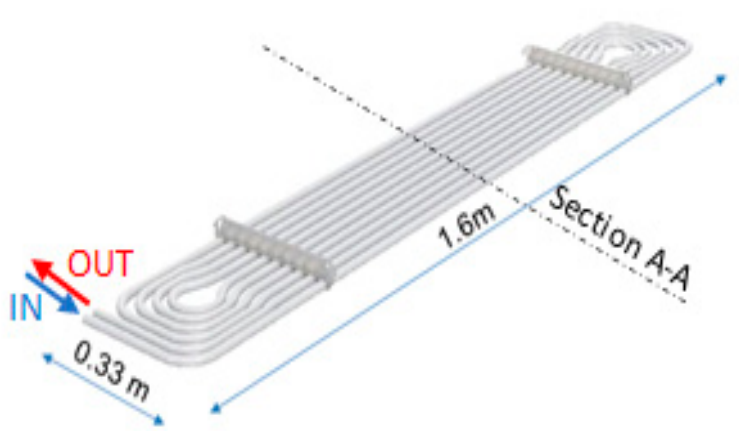

Section A-A

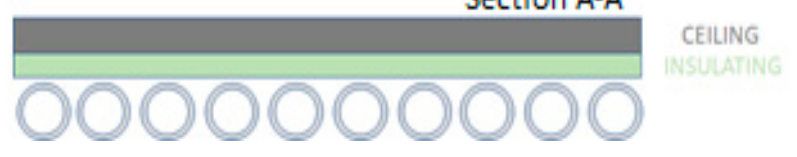

(b) Characteristics of a module

Figure 1. Technical detail of the studied system.

\subsection{Experimental Facility}

In order to be able to evaluate and characterise the solution experimentally, a test facility was built that simulated outdoor summer conditions. In this way, it was possible to have control over the excitations. The integration of the solution in a real pilot has been developed in Section 4.

The experimental prototype carried out to test the radiant solution took place in a test cell of $12 \mathrm{~m}^{2}$ (see Figure 2), located at the Eduardo Torroja Institute of Construction Sciences in the city of Madrid, Spain. It had the following characteristics:

1. Test cell cover: The radiant solution covered $10.5 \mathrm{~m}^{2}$ of the total gross surface, where the remaining $1.5 \mathrm{~m}^{2}$ corresponded to the space occupied by the impulsion and return pipes. The space between the roof and the radiant solution was fully insulated by $12 \mathrm{~cm}$ thick extruded panels.

2. Walls of the test cell: The space walls were made of wood up to $1 \mathrm{~m}$ high and glass up to $2.5 \mathrm{~m}$ high. All walls were insulated from the outside by $8 \mathrm{~cm}$ thick extruded honeycombs. 
3. Test cell floor: the cement floor was entirely covered by $8 \mathrm{~cm}$ thick extruded insulation panels.

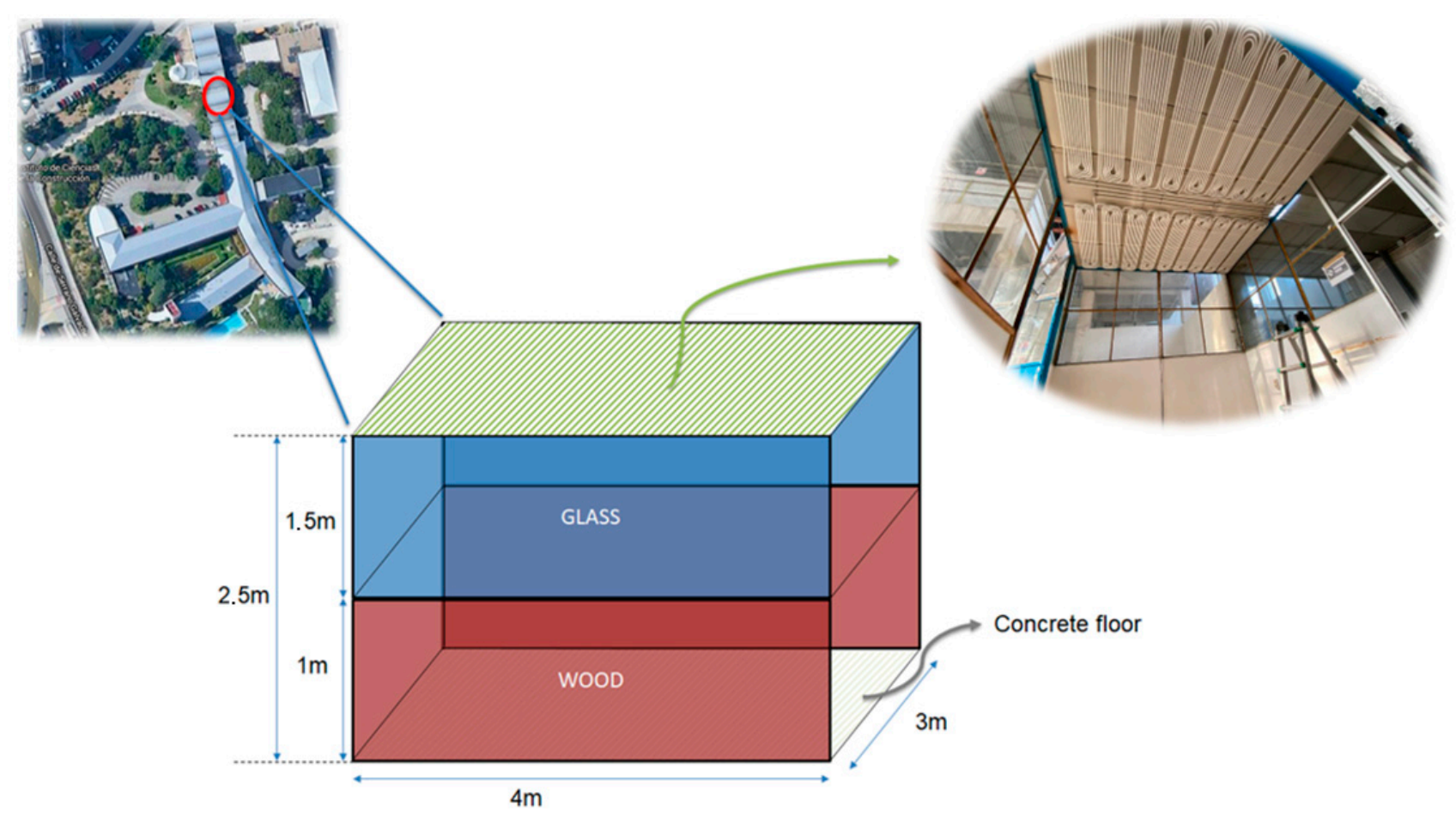

Figure 2. Test cell.

Figure 3 shows the outline of principles used for the tests.

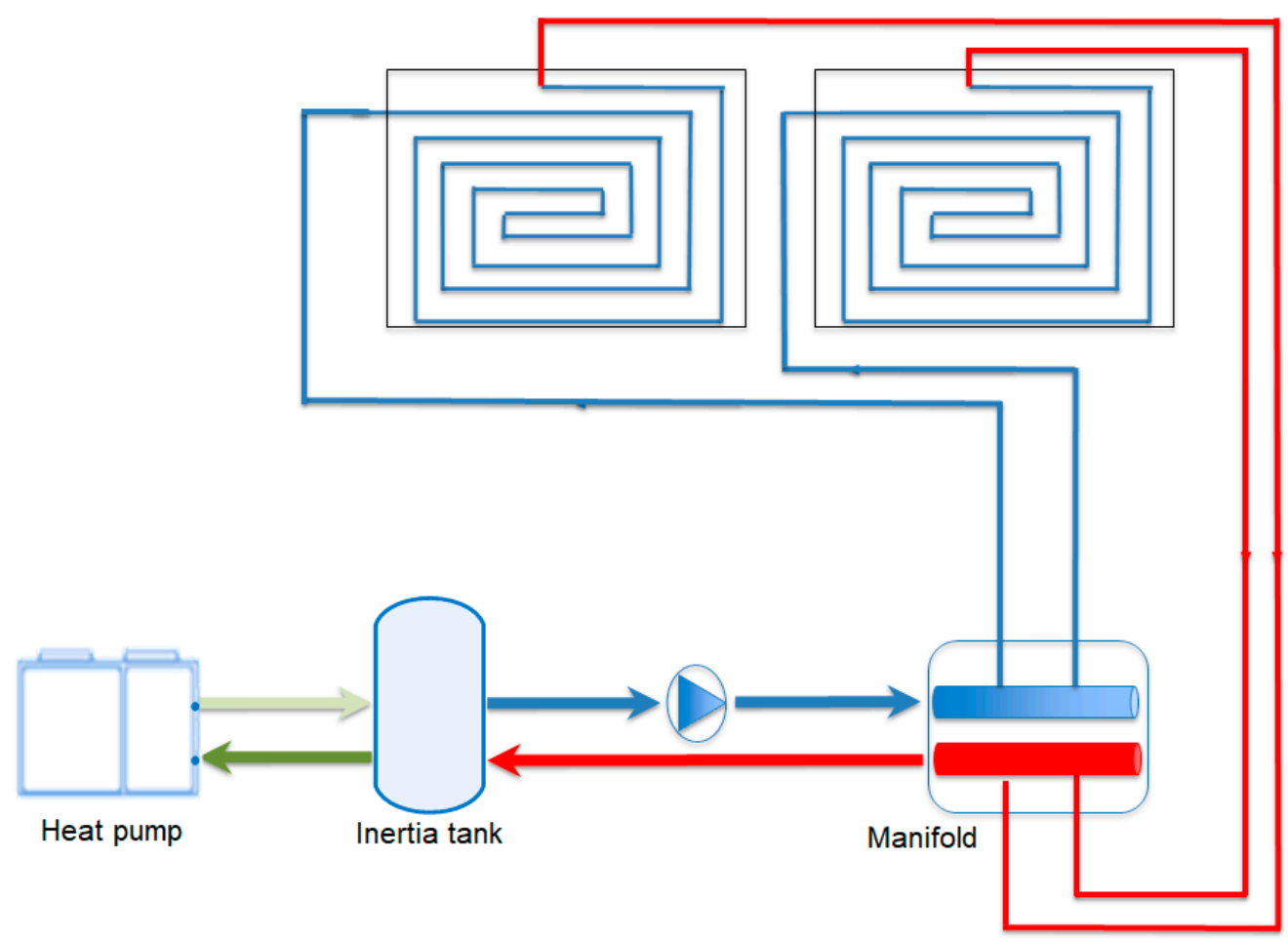

Figure 3. Hydraulic scheme of active surface.

The proposed experimental prototype consisted mainly of the radiant solution, a heat pump to cool or heat the water accumulated in the buffer tank, and a pump in charge of 
driving the water from the buffer tank to the radiant solution through a collector of supply and return of the two available circuits. The inertia accumulator had a protective coating, with a $160 \mathrm{~mm}$ thick synthetic wool thermal insulation and a capacity of $491 \mathrm{~L}$. The heat pump had a nominal heat output of $15.1 \mathrm{~kW}$ to heat the water in the tank to use the radiant solution in heating mode and a nominal cooling capacity of $17.4 \mathrm{~kW}$.

\subsection{Overview of the Experimental Set-Up: Test Cell}

To measure the performance of the radiant system, sensors for measuring air temperature, surface temperature, and water temperature were placed at the points indicated in Table 1. The thermocouples used were type $\mathrm{T}$ and were connected to a National Instruments Compaq DAQ data acquisition system with an accuracy of $0.8^{\circ} \mathrm{C}$. All thermocouples used were calibrated using a thermocouple calibration furnace to guarantee the measurements' quality.

Table 1. Description of sensors.

\begin{tabular}{ccc}
\hline Variable to Be Recorded & Type of Sensors & Measurement Points \\
\hline $\begin{array}{c}\text { Interior surface temperature } \\
\text { (see Figure 5-right) }\end{array}$ & Type T thermocouples & $\begin{array}{c}10 \text { (one for each face glass surface, } \\
\text { one for each wooden surface face, } \\
\text { the ceiling, and the floor) }\end{array}$ \\
\hline $\begin{array}{c}\text { Interior ambient temperature } \\
\text { (see Figure 5-left) }\end{array}$ & Type T thermocouples & 15 (5 for each height) \\
\hline $\begin{array}{c}\text { Water temperature } \\
\text { (see Figure 6) }\end{array}$ & Type T thermocouples & $\begin{array}{c}22 \text { (4 in the water tank, } 1 \text { inertial } \\
\text { tank outlet, } 1 \text { manifold inlet, } \\
2 \text { module inlets, } 4 \text { module inlets, } \\
4 \text { module outlets, } 2 \text { collector } \\
\text { returns, } 1 \text { collector outlet, } \\
1 \text { inertial tank inlet and } 1 \text { inertial } \\
\text { tank inlet and outlet-heat pump) }\end{array}$ \\
\hline
\end{tabular}

Figure 4 (left) shows the thermocouples corresponding to the air temperature of the test cell. Each red circle represents a thermocouple, with a total of fifteen distributed in the cell. This distribution allowed for monitoring and knowledge of the distribution of temperatures inside. Likewise, Figure 4 (right) represents the thermocouples corresponding to the surface temperature measurement. A total of ten sensors were distributed, as shown in the figure (yellow circles). These were placed by the different surfaces of the test cell in the central position of each face corresponding to walls (glass and wood), radiant solution, and floor.

Finally, Figure 5 shows the distribution of thermocouples (circles in orange) to measure water temperature. Also, four thermocouples were placed inside the tank at different levels and the water flows were measured at the inlet and outlet. Finally, a flow meter (grey diamond in Figure 5) was used to evaluate water energy variation. 


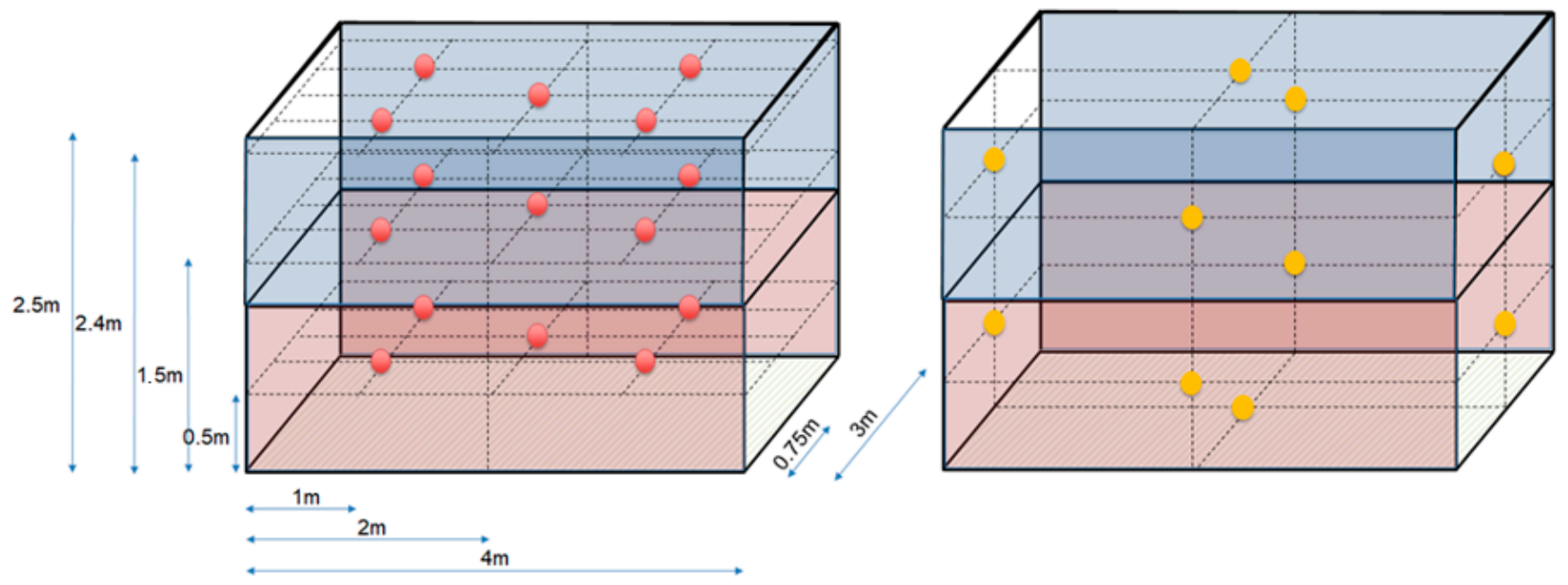

Figure 4. Test cell—position of sensors: air temperature (left) and surface temperature (right).

Type T

thermocouples

Flow meter

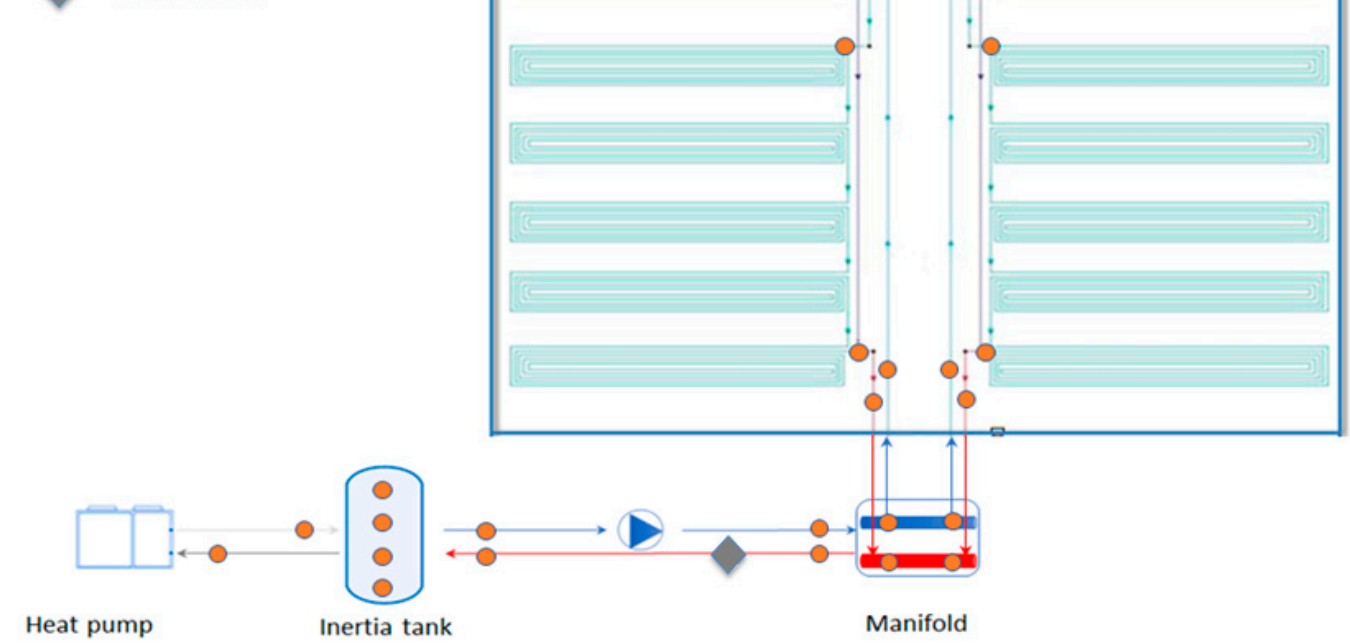

Figure 5. Test cell-position of water temperature sensors into the panel.

\subsection{Test Programme}

The radiant solution described has been tested in refrigeration mode under the following conditions:

- Both the ambient temperature and the average radiant temperature were not controlled. Only thermal excitation was carried out using a $4 \mathrm{~kW}$ fan coil and $1.2 \mathrm{~kW}$ radiators to simulate internal gains (conditions similar to the summer season). The temperature of the water in the tank was controlled. The heat pump cooled the water in the tank to the lowest possible temperature to obtain large temperature gradients between the average radiant temperature and the ambient temperature concerning the average temperature of the water that circulated through the radiant solution. 
- The adjustable variable was the flow. Each mode described below was tested under a range of flow rates between $2 \frac{1}{\mathrm{~min}}$ and $8 \frac{1}{\mathrm{~min}}$. These values corresponded to the total water flow.

The different modes of operation had in common the prior conditioning of the space by preparing the test cell. For the tests carried out under cooling conditions, during the night, the cell was conditioned by using a $4 \mathrm{~kW}$ fan coil and two radiators arranged in the central area of each circuit (see Figure 6). This guaranteed a high interior temperature in the early morning hours, thus obtaining the natural conditions of the cooling regime. In turn, the water in the tank was cooled to the lowest possible temperature. Therefore, it was possible to simulate the summer conditions within the test cell. It was necessary to check that the water was below $19{ }^{\circ} \mathrm{C}$ and that the average radiant temperature and ambient temperature were $6^{\circ} \mathrm{C}$ higher than the water tank's temperature. Once the test cell and the water in the tank were prepared, the following operating modes were carried out: mode 1-the fan coil was turned off, the oil radiators arranged in the central area of each circuit remained on, and the pump heat performance was measured. Under these conditions, the radiant solution started to work and was tested for an extended period (half of the experimental test period). Once mode 1 ended, mode 2 started. The heat pump was switched off to analyse the free evolution of the tank without external thermal support.
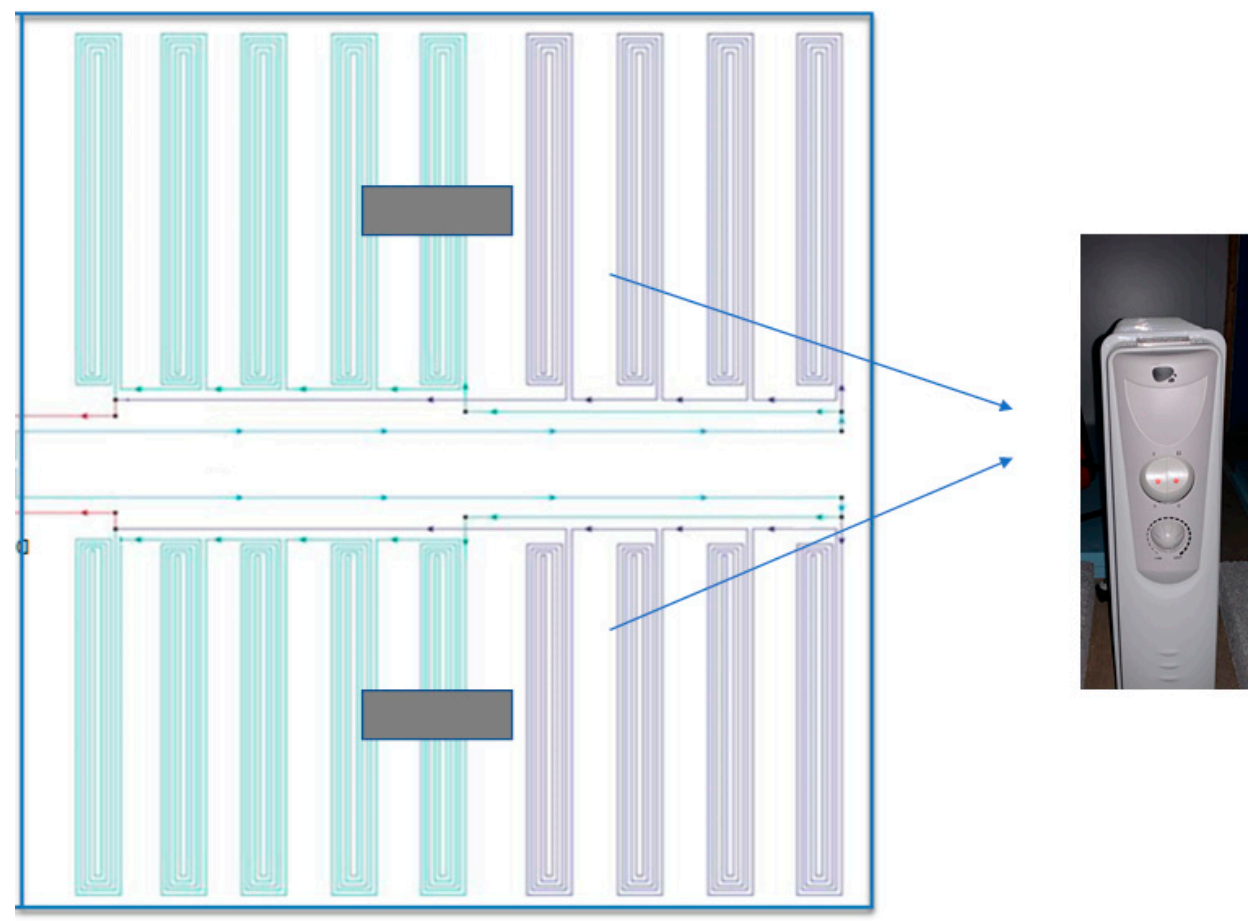

Figure 6. Heating radiator for simulating internal gains.

Finally, unlike in cooling mode, the heat pump was used to heat the water in the tank to a specific temperature in heating mode. Therefore, it was unnecessary to carry out the conditioning of the previous space in this operating mode since it was possible to guarantee a high-temperature gradient. In addition, the adjustable variable in this regime, as in cooling mode, was the water flow.

\section{Methods: Characterisation Model}

\subsection{Theoretical Basis}

The theoretical basis of the radiant system described is based on an energy balance. If the energy balance is carried out in an active roof system, wholly isolated from the top, the variation in water energy refers to the thermal gains or losses due to convection and radiation with the conditioned space $\left(Q_{c v}+Q_{\text {rad }}\right)$. 
Therefore, the energy variation of the water that circulates through the radiant cover is formulated according to Equation (1):

$$
m_{w} \cdot \rho_{w} \cdot C p_{w} \cdot \frac{d T_{w}}{d t}=Q_{c v}+Q_{\text {rad }}
$$

where $m_{w}$ is the flow of water that circulates through the radiant cover, $\rho_{w}$ the density of water, $C p_{w}$ the specific heat of the water, $\frac{d T_{w}}{d t}$ is the difference in temperature between the inlet and outlet of the water of the radiant system, $Q_{c v}$ is the convective heat flux between the surface and the surrounding air, and $Q_{\text {rad }}$ is the radiant heat flux between the surface and the rest of surface.

\subsection{Model}

The model developed is based on the theoretical foundations described in Section 4.1. Its parameters have been obtained from experimentation with an experimental prototype of the system described in Section 4.2. It was necessary to formulate a model to predict the absorbed or dissipated heat flux (cooling mode or heating mode). The main challenge was to characterise radiant heat flux. The total heat flux of the radiant system is shown in Equation (2):

$$
P=P_{c v}+P_{\text {rad }}
$$

where $P$ is the total absorbed or dissipated heat flux of the active roof system $\left(\frac{\mathrm{W}}{\mathrm{m}^{2}}\right), P_{c v}$ is the convective heat flux between the surface and the surrounding air, and $P_{\text {rad }}$ is the radiant heat flux between the surface and the rest of surface.

The convective flux is modelled according to Equation (3).

$$
Q_{c v}\left(\frac{\mathrm{W}}{\mathrm{m}^{2}}\right)=h_{c v} \cdot\left(L M T D_{c v}\right)
$$

where $L M T D_{c v}$ (Equation (4)) corresponds to the logarithmic mean temperature and $h_{c v}$ is the convective heat transfer.

$$
\operatorname{LMTD}_{c v}\left({ }^{\circ} \mathrm{C}\right)=\frac{\Delta T_{\text {in }}-\Delta T_{\text {out }}}{\operatorname{Ln}\left(\frac{\Delta T_{\text {in }}}{\Delta T_{\text {out }}}\right)}
$$

where $\Delta T_{\text {in }}$ refers to the temperature difference between the leaving water temperature and the ambient temperature and $\Delta T_{\text {out }}$ refers to the temperature difference between the return water temperature and the ambient temperature. Therefore, the use of the $L M T D$ implies the assumption that the temperature variation between both fluids is proportional to the temperature difference. This assumption has been validated by the data obtained from the experimentation.

The convective heat coefficient is modelled based on the Morgan correlation for a long horizontal cylinder [36] according to Equation (5).

$$
h_{c v i}=K_{i} \cdot L M T D_{c v}{ }^{n_{i}}
$$

The coefficients $K$ and $n$ are determined based on the data obtained from the experimentation of the experimental prototype. These coefficients vary depending on the regime (heating or cooling), so the value of $i=1$ is assigned for the cooling mode and $i=2$ for the heating mode. This is so because the cooling mode cools the surrounding air favouring its circulation (stratification), so a higher convective film coefficient is expected, while in heating mode, this convective film coefficient is much lower since the heating of the surrounding air does not generate air mass movement.

The absorbed or dissipated heat flux referred to the radiant thermal gains is linearised and is modelled according to Equation (6). The hypothesis is that the representative temperature difference is less than $100 \mathrm{~K}$ and, therefore, the error made when linearising the flux by radiation [37].

$$
Q_{\text {rad }}=h_{\text {rad }} \cdot L M T D_{\text {rad }}
$$


where $L M T D_{\text {rad }}$ corresponds to the mean logarithmic radiant temperature and is defined by Equation (7).

$$
\operatorname{LMTD}_{\text {rad }}\left({ }^{\circ} \mathrm{C}\right)=\frac{\Delta T_{\text {in }}-\Delta T_{\text {out }}}{\operatorname{Ln}\left(\frac{\Delta T_{\text {in }}}{\Delta T_{\text {out }}}\right)}
$$

where $\Delta T_{\text {in }}$ refers to the temperature difference between the leaving water temperature and the mean radiant temperature and $\Delta T_{\text {out }}$ refers to the temperature difference between the return water temperature and the mean radiant temperature.

The average radiant temperature is deduced based on the temperature of each of the cell surfaces by its corresponding form factor obtained using the EES software [38] and determined by Equation (8).

$$
T_{\text {rad }}\left({ }^{\circ} \mathrm{C}\right)=\sum_{i=1}^{8} f_{i} \cdot S T i+f_{\text {floor }} \cdot \text { ST floor }
$$

where STi is the surface temperature of each one of the walls (see Figure 7) and $f_{i}$ is the corresponding view factor concerning the radiant cover. $f_{\text {floor }}$ ST floor represents the product of the form factor corresponding to the soil with the cover and the surface temperature of the soil (See Figure 8).
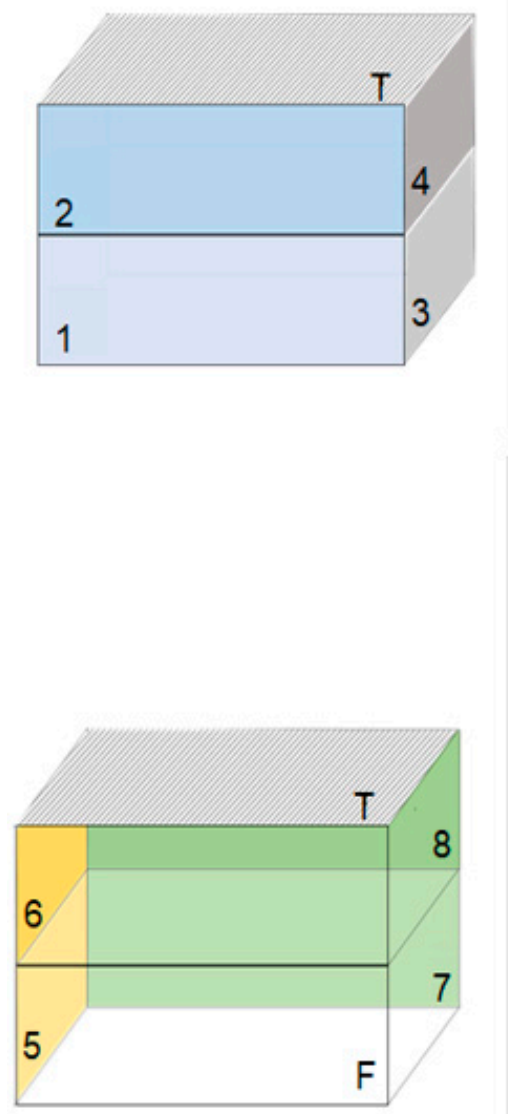
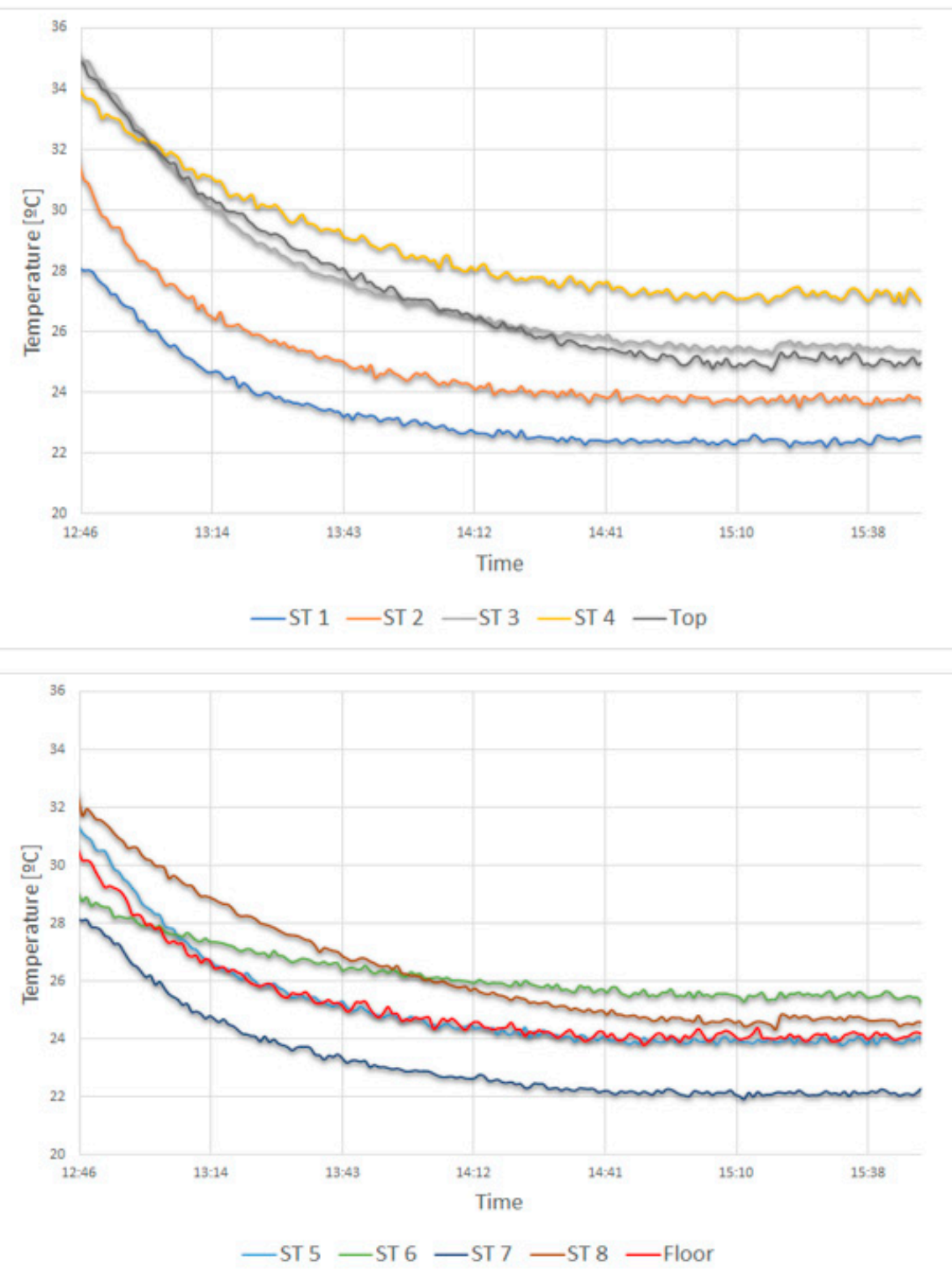

Figure 7. Experimental test: surface temperatures ST of different surfaces. 

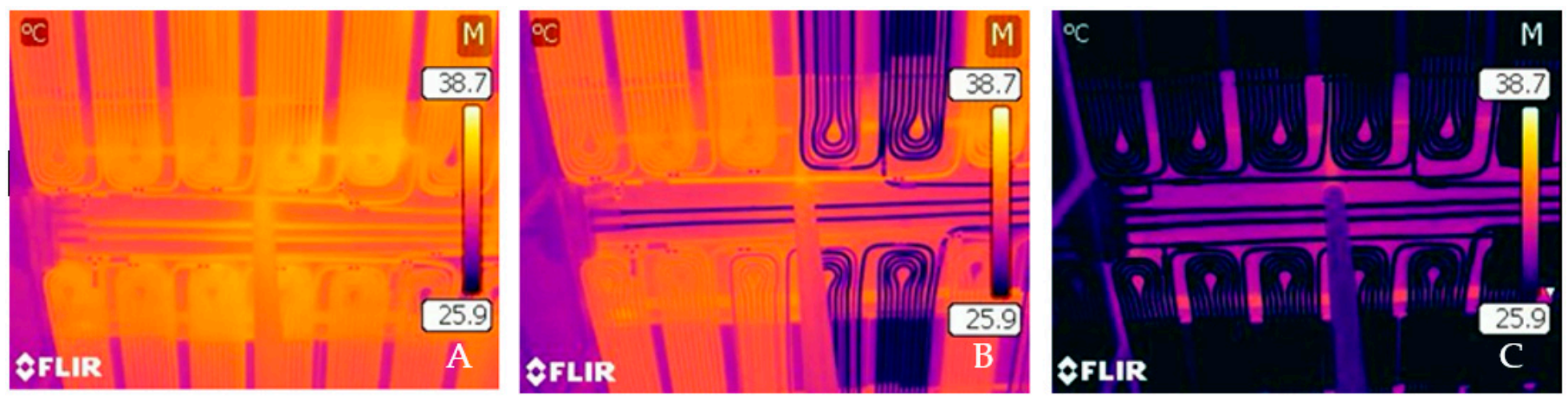

Figure 8. Thermography of active ceiling: cooling mode (A) before the start-up, (B) during start-up, (C) after $1 \mathrm{~h}$ of operation.

The radiant heat transfer coefficient is derived from the Stefan-Boltzmann equation for the emissive heat flux for a real surface. The following equation is used because the temperature difference between the water and the surrounding surfaces is less than $100 \mathrm{~K}$, so the linearisation of the radiant film coefficient can be applied (Equation (9)).

$$
h_{\text {rad }}=4 \cdot \varepsilon \cdot \sigma \cdot\left(\frac{T_{r a d}+\overline{T_{w}}}{2}\right)^{3}
$$

where $\overline{T_{w}}\left({ }^{\circ} \mathrm{C}\right)$ is assumed as the representative temperature corresponding to the average temperature of the water flow, $T_{r a d}\left({ }^{\circ} \mathrm{C}\right)$ is the mean radiant temperature and refers to the temperatures of the adjacent surfaces with the corresponding form factor to the radiant system, $\sigma=5.67 \times 10^{-8} \frac{\mathrm{W}}{\mathrm{m}^{2} \cdot \mathrm{k}^{4}}$ is the Stefan-Bolzmann constant, and $\varepsilon$ is the emissivity, which is determined based on experiments.

Finally, it is necessary to determine the return temperature of the water that circulates through the radiant cover. The return water temperature is determined according to Equation (10) [36].

$$
T_{\text {water out }}=T_{e q}-\left(T_{e q}-T_{\text {water in }}\right) \cdot e^{-\frac{U \cdot A}{\dot{m} \cdot c_{p}}}
$$

where $U\left(\frac{\mathrm{W}}{\mathrm{m}^{2} .{ }^{\circ} \mathrm{C}}\right)$ is refers to the global transfer coefficient corresponding to the sum of the convective film coefficient (Equation (5)) and the radiant transfer coefficient (see Equation (9)), $A\left(\mathrm{~m}^{2}\right)$ is the projected area as a function of the number of modules that the active cover has, $\dot{m}\left(\frac{\mathrm{kg}}{\mathrm{s}}\right)$ refers to the mass flow, $T_{\text {water in }}$ is the mean temperature of discharge water, and $T_{e q}$ is the equivalent heat transfer temperature (Equation (11)).

$$
T_{e q}=\frac{h_{r a d} \cdot T_{r a d}+h_{c v} \cdot T_{a}}{h_{r a d}+h_{c v}}
$$

So, thermal identification of the model requires solving the value of $K, n$ (see Equation (5)) and $\varepsilon$ (see Equation (9)) using the experimental test in heating and cooling modes. The following section shows details about experiments and the results of the identification.

\section{Results}

\subsection{Analysis of a Typical Test}

Continuous monitoring makes it possible to obtain the necessary data to determine the variables needed to calculate the radiant system's heat flux absorbed or dissipated. Figure 7 shows experimental results of surface temperature "ST". Likewise, the floor is represented by "F" and the ceiling by " $\mathrm{T}$ " in Figure 7. These data belong to a test carried out for a flow rate of $2 \frac{1}{\min }$ and combined operation modes 1 and 2 described above.

Figure 7 shows the evolution of surface temperatures. Each period is linked to mode 1 (first period) and 2 (second period). During the first period, the water temperature did not exceed $15{ }^{\circ} \mathrm{C}$. Then, the temperature of the surfaces decreased rapidly due to the radiant effect of the ceiling. When the heat pump was off (mode 2), the radiant system's absorption capacity diminished since the temperature difference reduced. These types of tests were repeated with different operating conditions to characterise the solution. 
The hydraulic circuit that involves the radiant system was fully monitored, as specified in the previous section. Figure 8 shows different thermographic images. Here, it is possible to visualise the contrast of temperatures throughout the fluid through the modules and even the surface temperature just above the radiant cover.

The images of Figure 8 correspond to the test the water flow of $8 \frac{1}{\mathrm{~min}}$ but at different times. The first one (Figure 8A) corresponds to the system completely off (no water circulates). The second one (Figure $8 \mathrm{~B}$ ) took place during the minutes after starting, in which the average water temperature showed the temperature difference between the water and the surroundings. The water temperature was around $19^{\circ} \mathrm{C}$ and the surface temperature and air temperature of the space were $28^{\circ} \mathrm{C}-30^{\circ} \mathrm{C}$. The third image (Figure 8C) shows the temperature after one hour.

Finally, Figure 9 shows an example of a combination of the operating modes for $8 \frac{1}{\mathrm{~min}}$. Thanks to the surface temperatures and the different shape factors, it was possible to determine the mean radiant temperature (see Equation (8)).

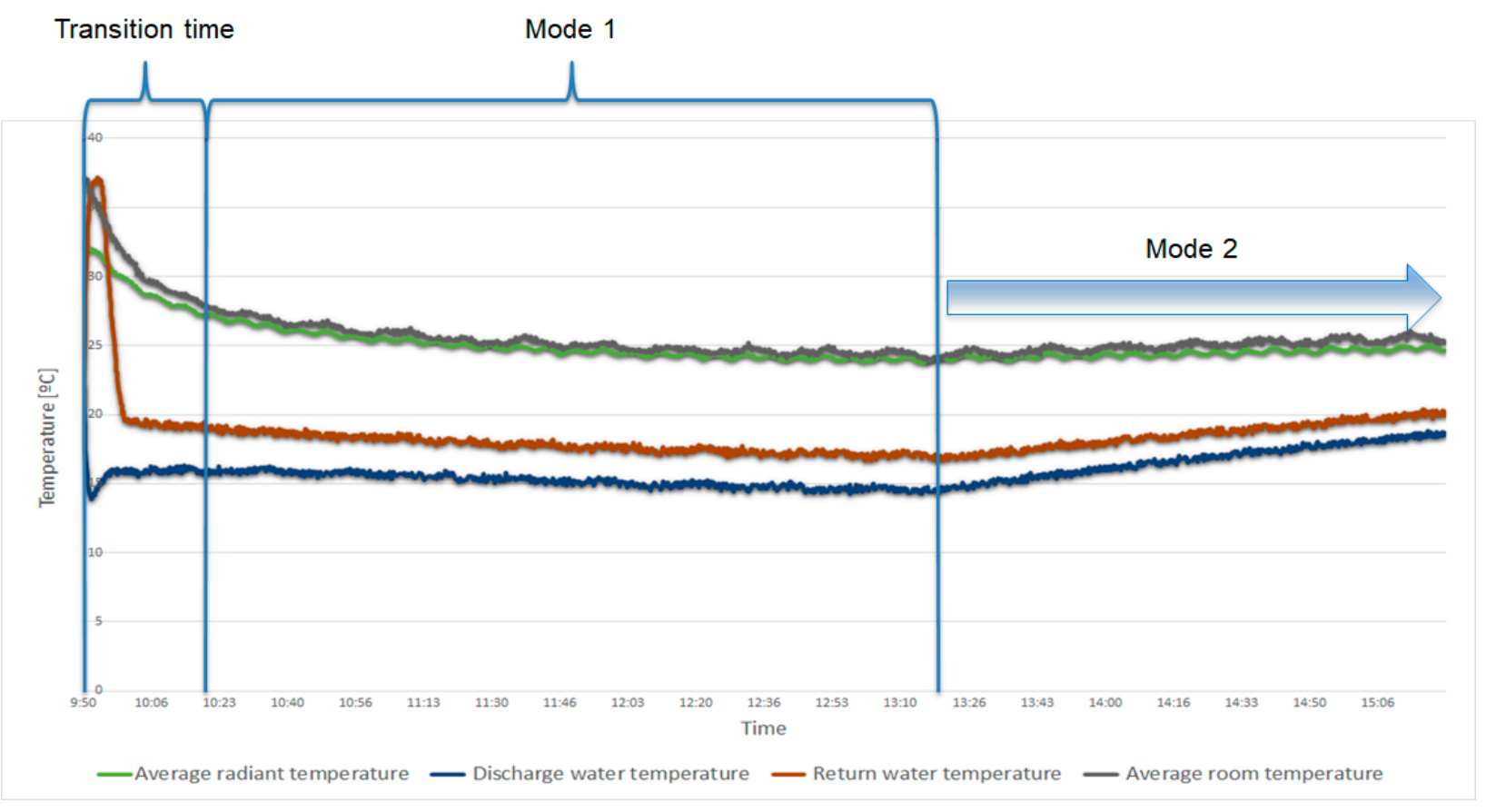

Figure 9. Experimental results: water temperature vs. average of radiant and air temperature.

Figure 9 is an example of the data treatment during the three periods. First, transition time appears at the beginning, this was period 1 (see Figure 9). The duration of period 1 was around $30 \mathrm{~min}$. Period 2 (mode 1 in Figure 9) began when the heat pump was on. During period 1, it was possible to guarantee a constant temperature difference due to the heat pump's operation. Also, mode 2 is essential to ensure the free running when the water is not controlled (heat pump is off).

\subsection{Comparison of Flow Effect}

The operating modes described above and the flow rate, which is the only regulation variable of this system, are represented in Figure 10. This figure shows three experimental cases belonging to the cooling mode, in which the operating modes were combined for the same test with a given flow.

All the tests combined operating modes 1 and 2 for different proposed flow rates. The main difference was the average water temperature. This difference refers to the thermal jump between the driven and the return water. As the total discharge flow was reduced, the temperature gradient between the discharge and the water return was higher than in the other cases. 


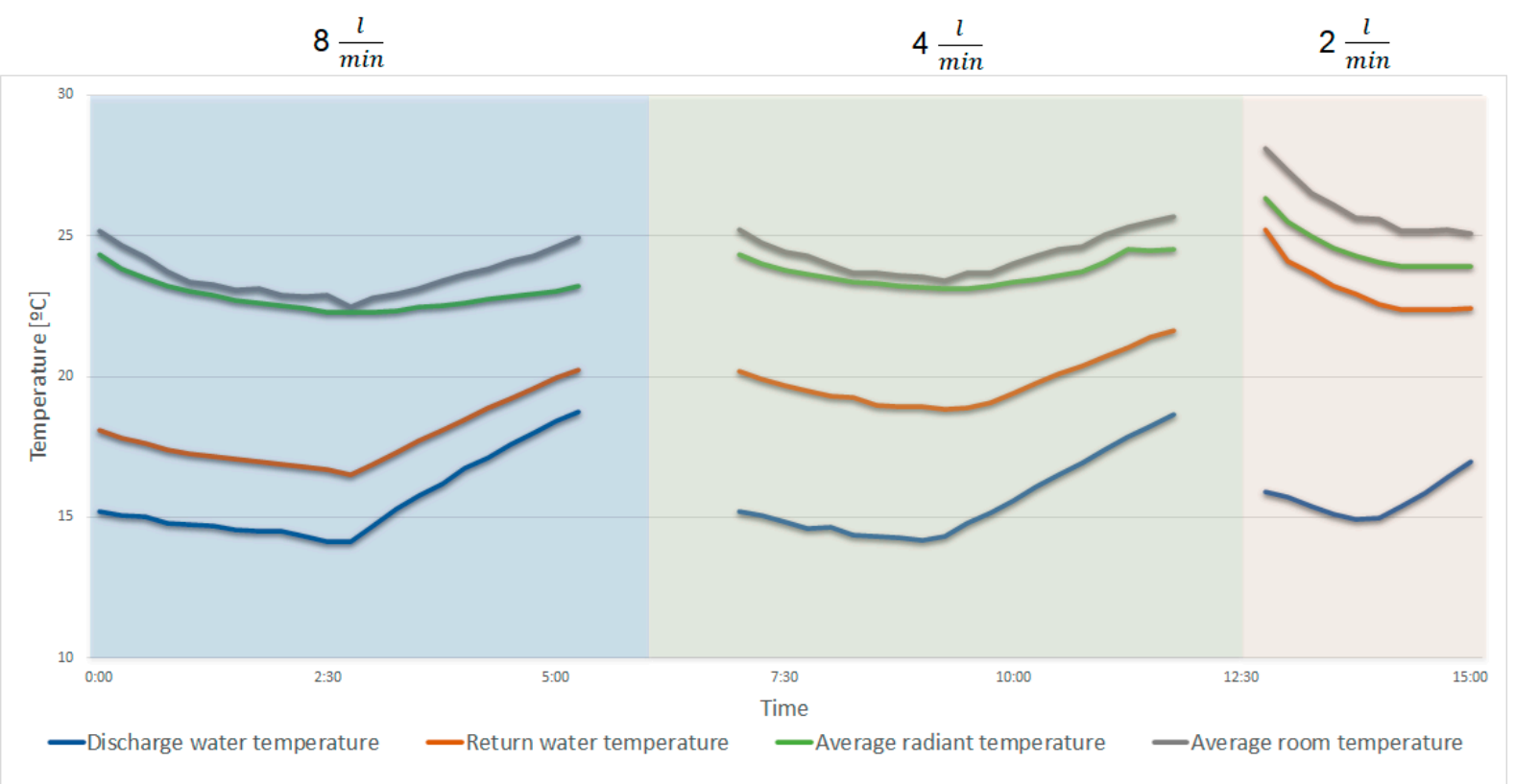

Figure 10. Water flow variation-analysis of radiant and air mean temperatures and water temperatures.

\subsection{Identification of Parameters and Validation}

As previously mentioned, the model parameters have been obtained with the results of the experimental prototype of the radiant roof system. The parameters to be determined were the coefficients $K$ and $n$ (see Equation (5)) of the convective film coefficient in heating and cooling mode. These parameters were determined by applying least squares to a subsample of the results obtained.

Figure 11 shows the total heat flux, absorbed when the cover was in cooling mode (left) and dissipated when in heating mode (right). In both cases, it was a function of the water temperature difference for various flow rates tested. The total heat flux was measured for different water flows and water temperature differences (see Figure 10).
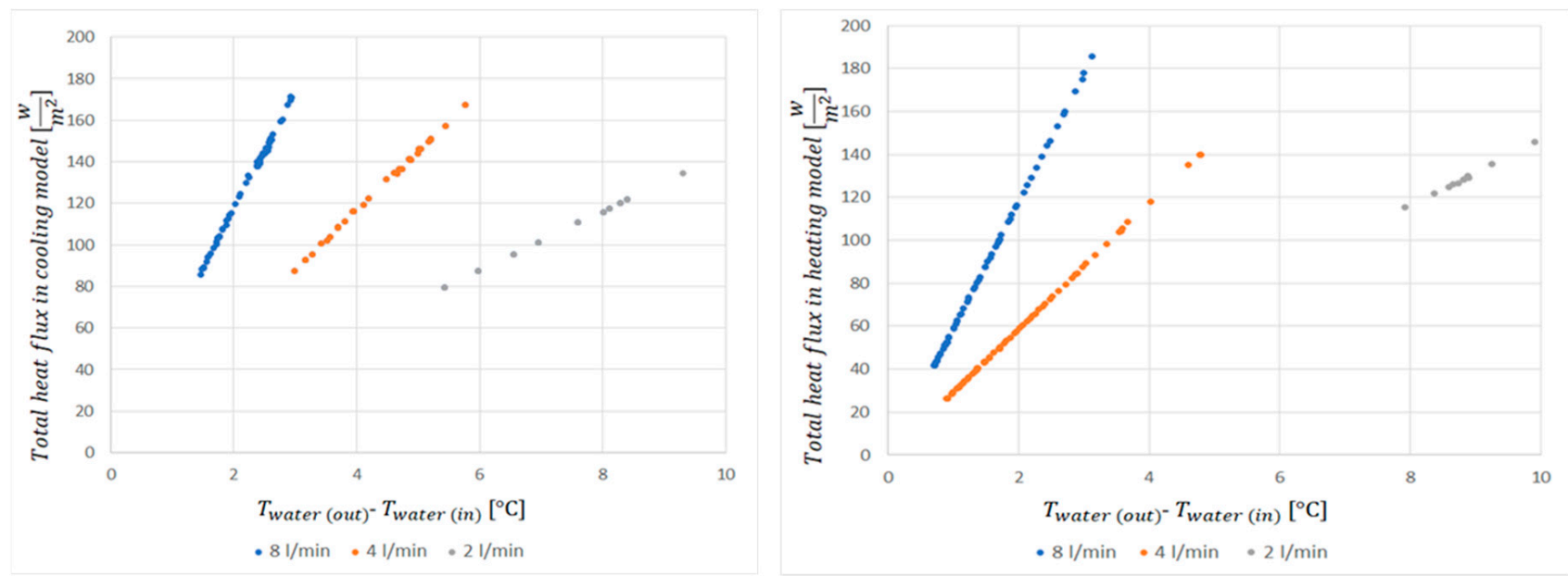

Figure 11. Total heat flux. Cooling mode vs. heating mode.

For both heating and cooling mode, as the flow through the radiant cover was reduced, the thermal jump of the water between the inlet and the outlet was higher for the same given total heat flux. As described in Equation (5), the total absorbed heat flux was broken down into convective heat flux and radiant heat flux. The radiant heat flux varied as a 
function of the thermal jump between the average water temperature $\left(\overline{T_{W}}\right)$ and the average radiant temperature $\left(T_{\text {rad }}\right)$ of the cell in which the radiant ceiling is located. Figure 12 shows the behaviour of radiant heat flux in both cooling (left) and heating (right) mode compared to $L M T D_{\text {rad }}$. Also, it is necessary to know the emissivity of the material used. Emissivity is estimated by an identification procedure using a comparison between experimental data and estimation from the model. Starting from the premise that construction materials have an emissivity between 0.7 and 0.9 . The emissivity obtained was 0.85 .
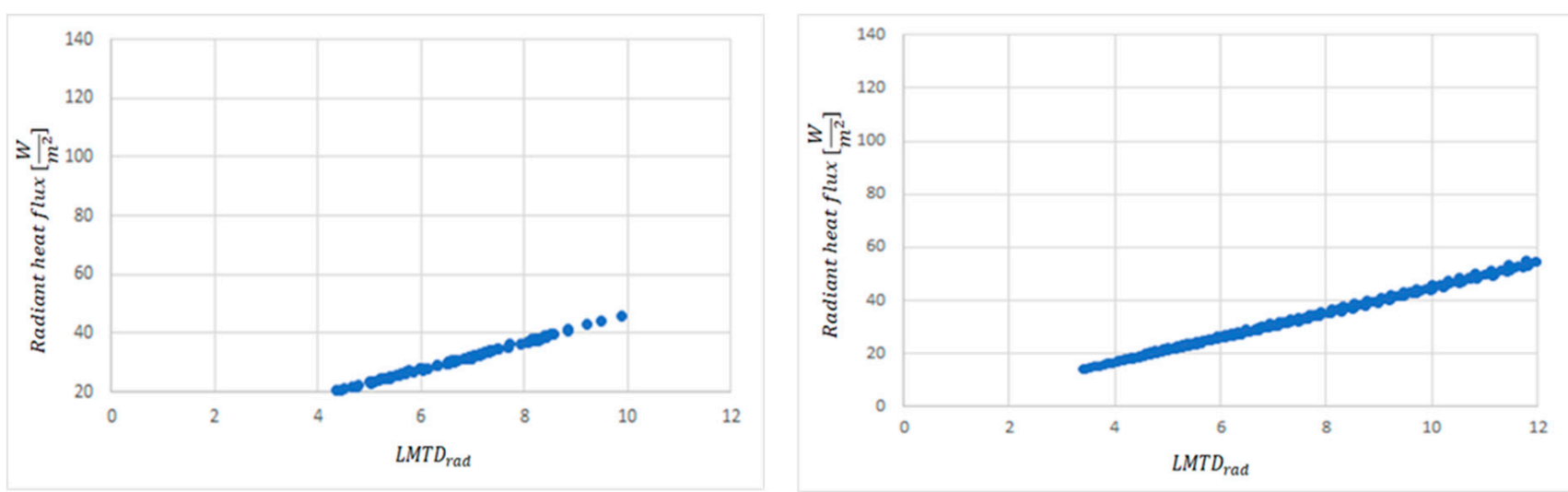

Figure 12. Radiant heat flux. Cooling mode vs. heating mode.

This linearity in the results obtained translated into a radiant transfer coefficient that was practically constant for both the cooling and heating modes. It was observed that, at the same temperature difference, the radiant heat flux obtained was higher in heating mode than in cooling mode. It implies an average $h_{\text {rad }}$ of $4.6 \frac{\mathrm{W}}{\mathrm{m}^{2} \cdot{ }^{\circ} \mathrm{C}}$ for the system in cooling mode and $6.2 \frac{\mathrm{W}}{\mathrm{m}^{2} .{ }^{\circ} \mathrm{C}}$ for heating mode.

The convective heat flux obtained in the experiments carried out as a function of the $L M T D_{c v}$ is shown in Figure 13 for heating and cooling modes.
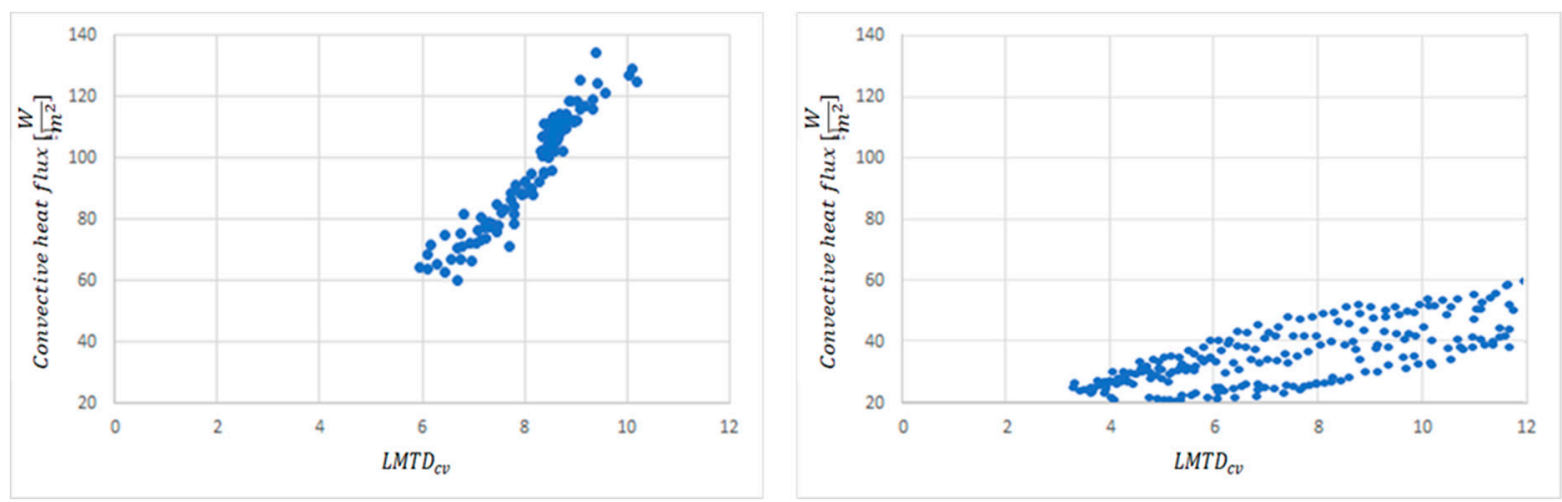

Figure 13. Convective heat flux. Cooling mode (left) vs. heating mode (right).

As shown in Figure 13, convective heat flux was higher in cooling than heating mode for the same difference in water temperature. This occurred because the cooling mode stimulated air movement (cold ceiling) due to a buoyancy effect. Also, the results of Figure 13 allow for an estimation of the convective heat transfer (Equation (5)). Figure 14 shows the results of the convective heat transfer evolution. 


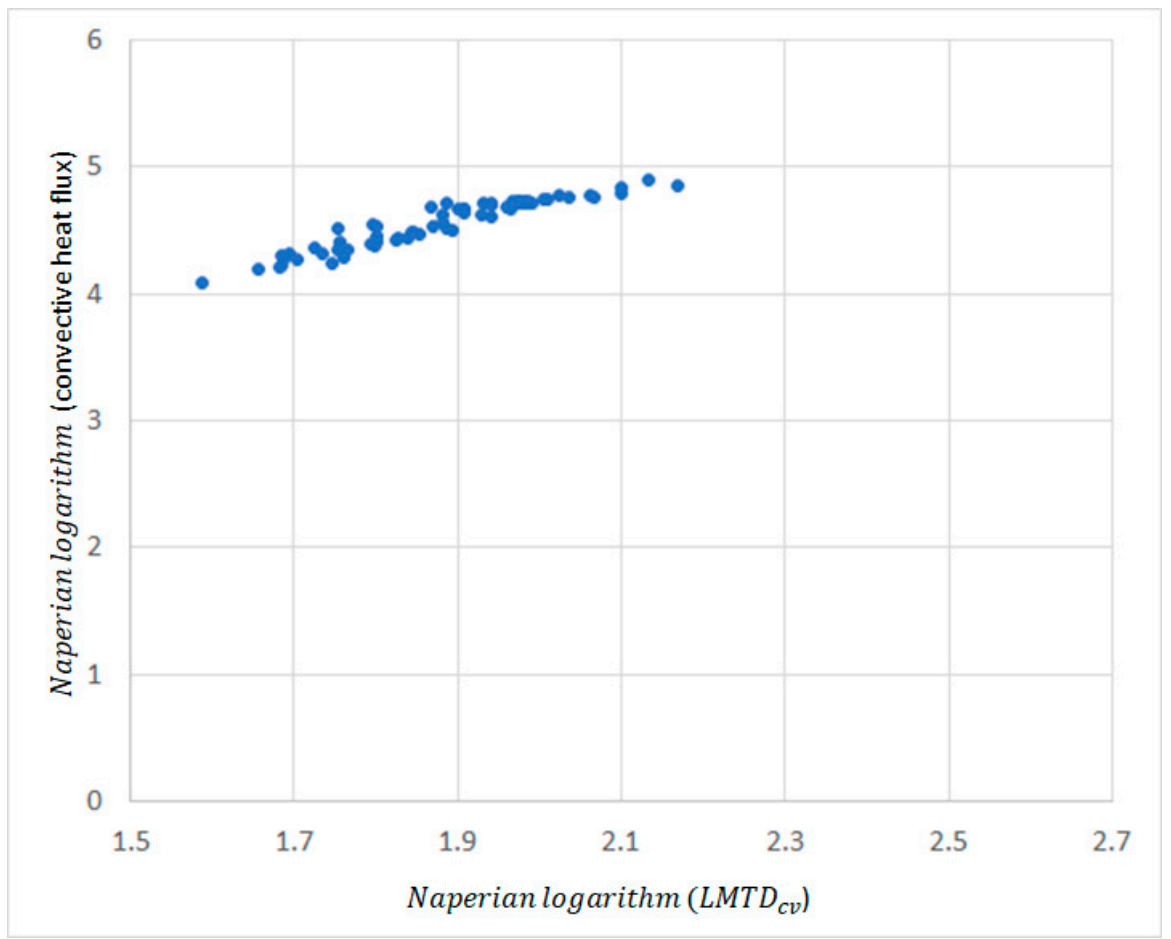

Figure 14. Obtaining model parameters. Naperian logarithm (convective heat flux) vs. Naperian logarithm $\left(L M T D_{c v}\right)$.

It was possible to adjust the expression (see Equation (5)) using data from Figure 14. Experimental data were divided into two groups: group 1 identified the coefficients ( $40 \%$ of the experimental data) and group 2 validated the expressions ( $60 \%$ of the data). Coefficients for Equation (5) were different for heating and cooling modes. Equation (12) shows the result for cooling mode and Equation (13) for heating mode.

$$
\begin{gathered}
h_{c v 1}=\mathrm{e}^{1.8127} \cdot \text { LMTD }_{c v} 0.4596 \\
h_{c v 2}=\mathrm{e}^{0.83} \cdot \text { LMTD }_{c v} 0.2975
\end{gathered}
$$

The validation of the proposed model in cooling mode is given by executing the model with the input data (air temperature, temperature of surrounding surfaces, water flow, and water inlet temperature). There were two results that needed to be validated: total heat flux and water outlet temperature. Figure 15 compares the estimated and measured values of total heat flux (left) and water outlet temperature (right).

The results obtained with the proposed model in cooling mode presented an average relative error of $2.9 \%$ concerning the measured heat flux, thus verifying the efficiency and quality of the proposed model. Also, the water outlet temperature was a key result of the model. Figure 16 (right side) shows the acceptable estimation of the model. The analysis of the water outlet temperature presented an average relative error of less than $0.6 \%$, which is why an exhaustive knowledge of it is guaranteed with applying the proposed model. Also, the results obtained in heating mode showed an average relative error lower than that of cooling, of only $2.4 \%$ concerning the measured heat flux. At the same time, the estimation of the water leaving temperature only showed a mean deviation of $0.5 \%$. 

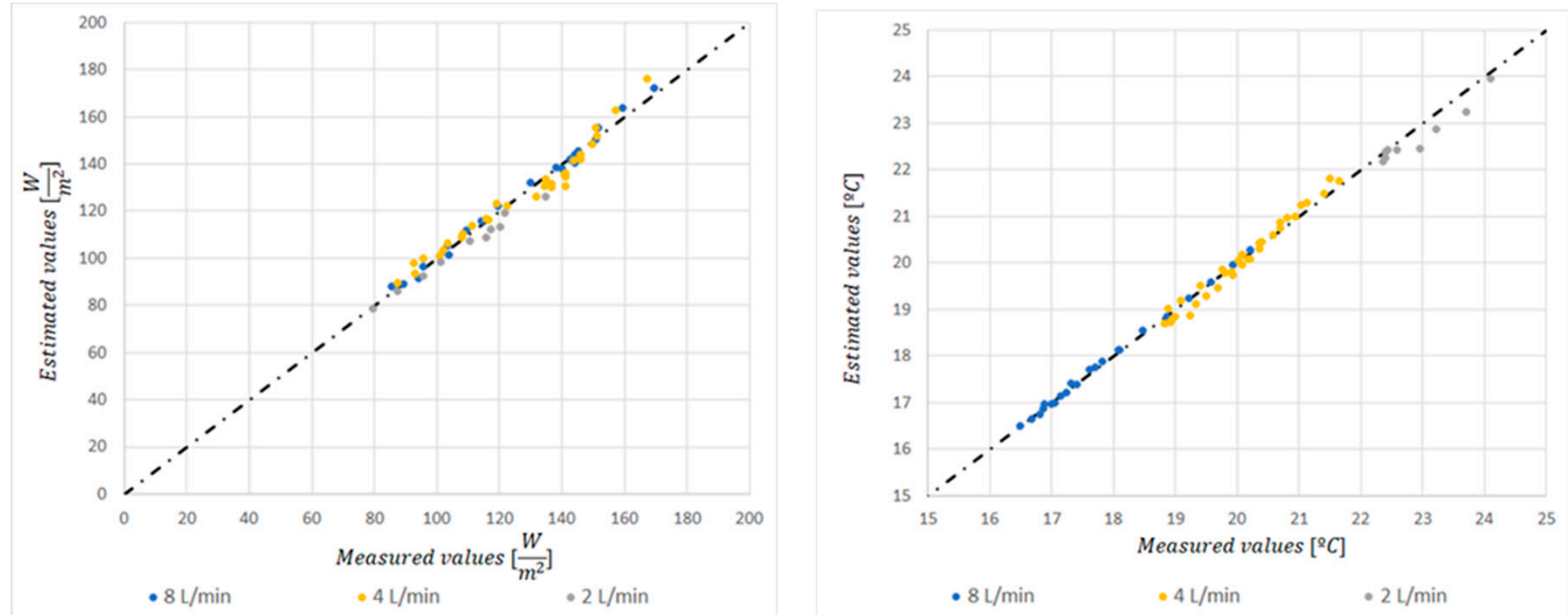

Figure 15. Validation. Total heat flux: estimated vs. measured values (left). Water outlet temperature: estimated vs. measured values (right).
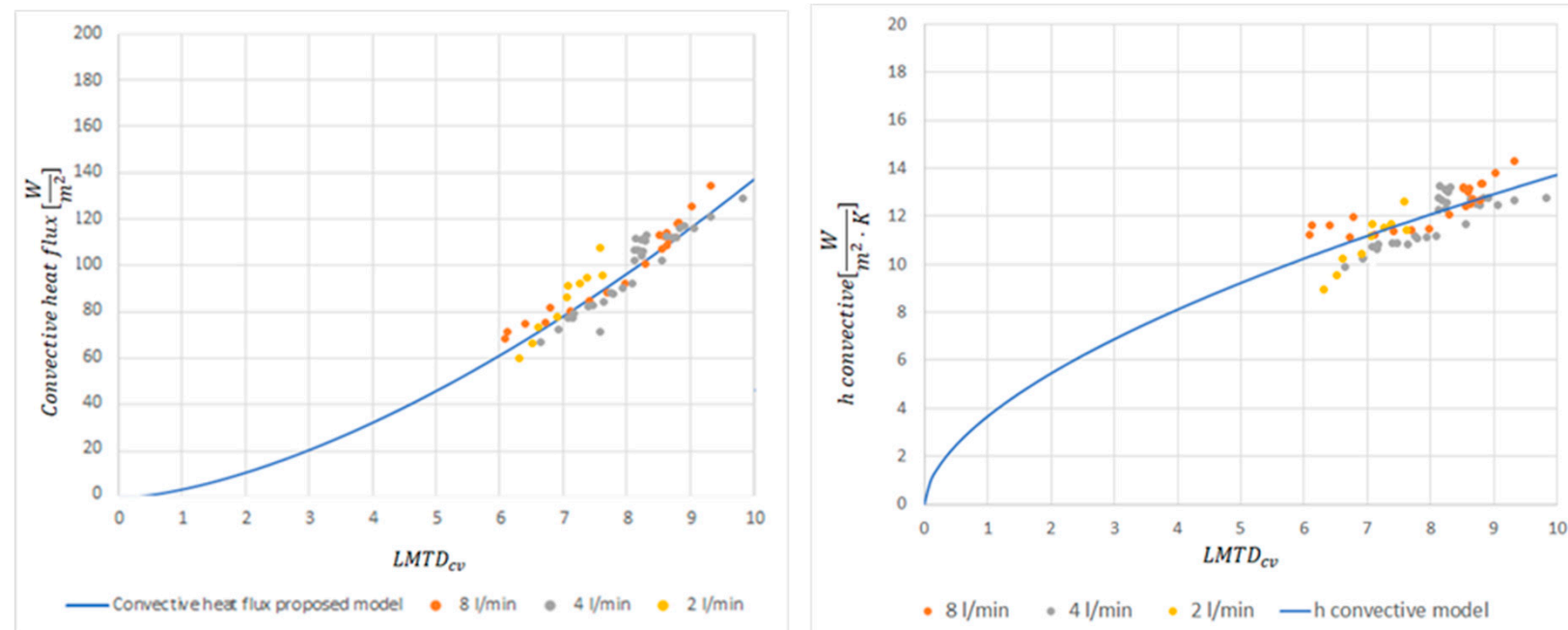

Figure 16. Cooling mode. Convective heat flux (left) and convective heat transfer coefficient (right) as a function of representative temperature difference $L M T D_{c v}$.

Figure 16 shows the convective heat flux (left) validation and heat transfer coefficient (right, $h_{c v 1}$ since Equation (12)) in cooling mode. Figure 17 shows the same results for heating mode. In this case, the convective heat transfer coefficient was the $h_{c v 2}$ value from Equation (13).

Figures 16 and 17 allow for analysis of validation results of convective heat flux. On the one hand, the average relative error of the convective heat flux was $1.4 \%$. This result verifies the efficiency and quality of the proposed model. On the other hand, the relative error of convective heat transfer coefficient estimation was $1.7 \%$. This is considered an acceptable error.

Finally, it is important to highlight that the estimation in heating mode is more accurate than cooling mode. It is due to the difficulty of measuring the local effects of air movement by buoyancy. However, the results prove the validity and robustness of the model. 

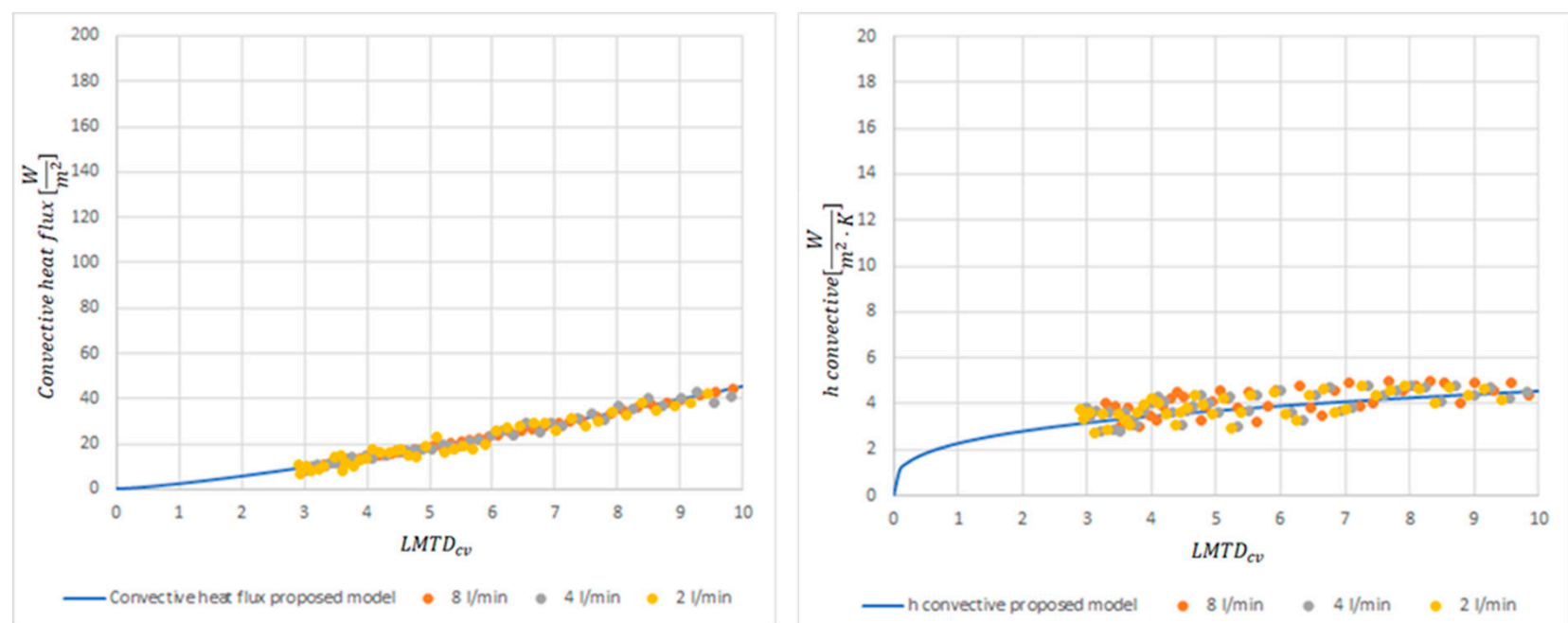

Figure 17. Heating mode. Convective heat flux (left) and convective heat transfer coefficient (right) as a function of representative temperature difference $L M T D_{c v}$.

\section{Discussion and Applicability of Results}

The European project of conditioning open spaces to recover life in the street UIA03-301-CartujaQanat of Urban Innovative Action (UIA) has generated the need to develop new techniques for conditioning open spaces in order to characterise them. One of the techniques is the heating/cooling of surfaces without the consumption of water. For that, the studied solution has been designed, tested, and characterised. Results of this study have allowed for the integration of this solution in a new open space, the project's pilot. The second stage studies the integration of the solutions studied in an open space. This space is a semi-buried open space of $750 \mathrm{~m}^{2}$ (see Figure 18).

The climatic control solution of this space will be used as natural technique to produce cold and hot water for intensive use in the summer and winter. Nevertheless, summer weather conditions are extreme in Seville (the hottest zone in Spain), so the space is sized to achieve thermal comfort in cooling conditions. Likewise, the systems of the pilot, even the solution, can operate in heating mode, but there will be few hours of the year in which its operation is required. The treatment proposed the generation of thermal comfort conditions and reduction of solar gains, the entry of outside air into the volume to be conditioned, and the impulsion of air, but it is impossible to achieve this without controlling the temperature of the surfaces [39]. In this aspect, the cover of the souk plays a fundamental role. The ceiling is the dominant form factor of the occupant. As it is an open space, the air near the surface will be air at an outside temperature far from the space to be conditioned. So, the convective effect of this solution is not attractive.

For this reason, in the first stage of the project, it was decided to study alternatives that allow for achieving a hot or cold surface according to the needs. As a result of this work, a radiant solution adapted to the outdoors is proposed. The solution presented in this work has been modelled, tested, and characterised by building a coherent prototype. All this to achieve a high level of knowledge of the system, especially the radiant effect, to carry out the design and evaluation of the integration of the solution on the roof of said space in the second stage of the project. Currently, this project is in the execution phase. So, the real impact of the solution will be measured on-site in the future. 

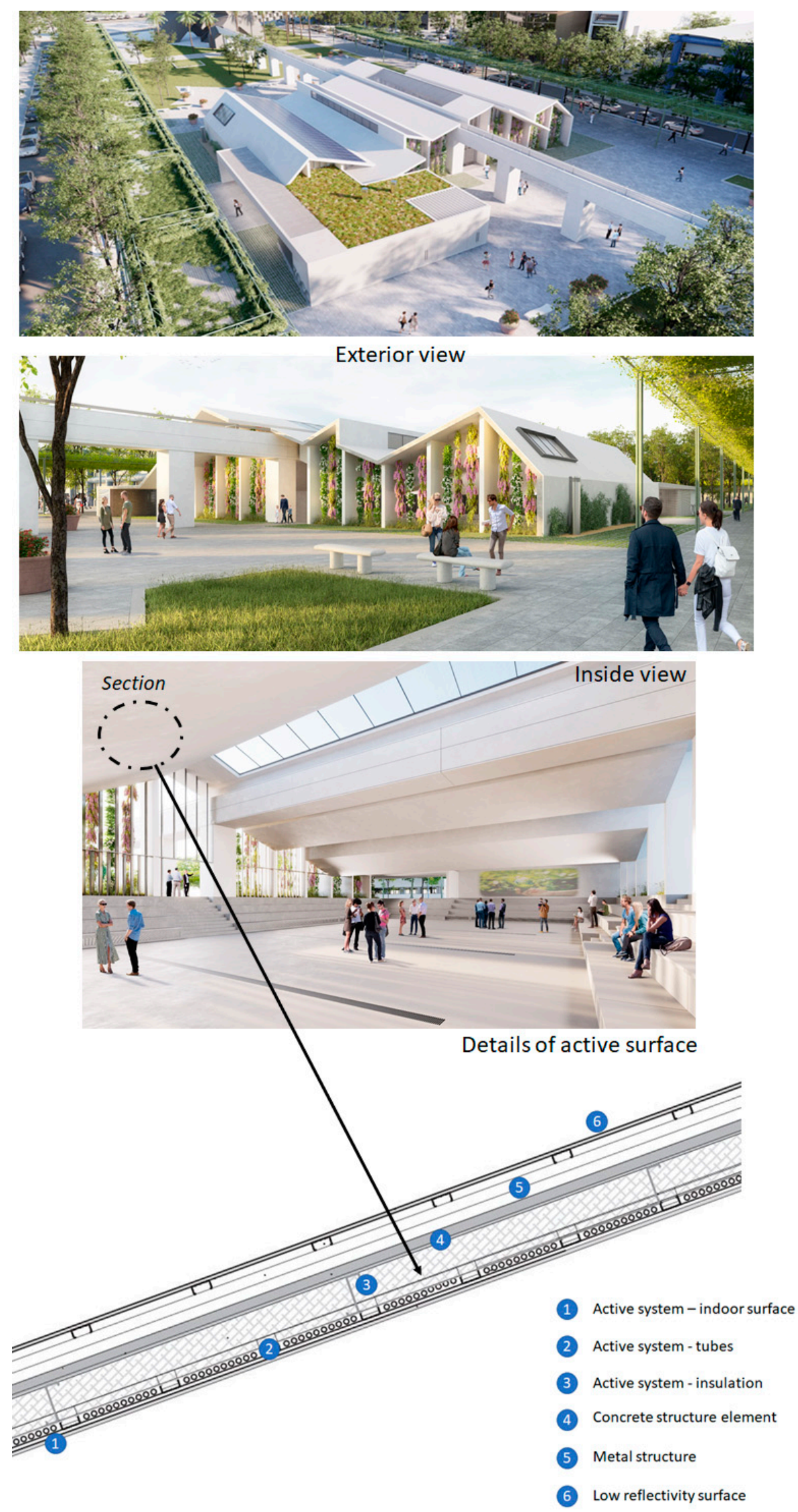

Figure 18. Design of climatic outdoor conditioning system by radiant surface in the open space (case of study). 
This space's comfort needs (summer conditions) have been obtained following the procedure described by Santamouris et al. [40]. These can be summarised as follows: block the solar gains inside the space, achieve an air temperature lower than $29^{\circ} \mathrm{C}$, control relative humidity between $30 \%$ and $70 \%$, and, above all, maintain an average radiant temperature lower than or equal to $28^{\circ} \mathrm{C}$. All this was calculated for conditions of $39^{\circ} \mathrm{C}$ outside temperature, global horizontal radiation of $950 \mathrm{~W} / \mathrm{m}^{2}$, and a wind speed of $4 \mathrm{~m} / \mathrm{s}$. Now, the view factor between the occupant and the space's ceiling is greater than $50 \%$. The rest is practically the floor and the half-buried walls. (see Figure 18). In order to guarantee an average radiant temperature of $28^{\circ} \mathrm{C}$, the cover must be at a temperature lower than $26^{\circ} \mathrm{C}$. To achieve this effect, the solution proposed in this paper should be used. In winter conditions, the comfort requirements would force the roof to maintain a temperature above $30{ }^{\circ} \mathrm{C}$. As has been commented, the design of the space is done based on a summer regime. It is due to the extreme climatic conditions

The proposed model requires design and sizing of the active ceiling to incorporate active modules of solution (length and diameter of tubes), a number of modules connected in series (circuits), and sizing of the hot/cold water production system. Also, it is possible to estimate thermal behaviour in any operational conditions. Then, this section shows the optimal way for integrating the solution.

The applicability of the proposed model and the correlations obtained based on experimentation allow replicating the tested technology under any conditions and knowing the system's performance under different operating conditions. For this, NTU's efficiency method is proposed as it is most used for the design and dimensioning of heat exchange systems [41,42]. Efficiency is the indicator that shows the quality of the future designs carried out, and the $N T U$ parameter is linked to the dimensioning of the element.

Efficiency is defined as the quotient between the temperature difference in the fluid that circulates through the active surface and the maximum possible temperature difference. This water temperature difference corresponds to the difference in the water flow temperature and the equivalent room temperature (See Equation (14)).

$$
\varepsilon=\frac{T_{\text {water in }}-T_{\text {water out }}}{T_{\text {water in }}-T_{\text {eq }}}
$$

The number of transfer units (NTU) is defined in Equation (15):

$$
N T U=\frac{U \cdot A}{C_{\min }}
$$

where $T_{\text {water in }}\left[{ }^{\circ} \mathrm{C}\right]$ is the inlet water temperature and $T_{\text {water out }}\left[{ }^{\circ} \mathrm{C}\right]$ is the outlet water temperature of the radiant element, $T_{e q}\left[{ }^{\circ} \mathrm{C}\right]$ is the equivalent convective radiant temperature linked to the room (see Equation (11)), $U\left[\frac{\mathrm{W}}{\mathrm{m}^{2} \cdot \mathrm{K}}\right]$ is the heat transfer coefficient (see Equation (10)), $A\left[\mathrm{~m}^{2}\right]$ is the active surface of the radiant element, and $C_{\min }\left[\frac{\mathrm{W}}{\mathrm{K}}\right]$ is the thermal capacity of water flow inside the tubes. The active surface relates to the size of the element. Also, the $U$-value is linked with the thermal characteristic of water flow (convection).

Furthermore, the efficiency can be approximated as a function of the NTU using the expression proposed by Bergman [37] in Equation (16):

$$
\varepsilon=1-e^{-\mathrm{NTU}}
$$

The procedure allows for assessment in different operating conditions and designs. The following results demonstrate the influence of design parameters. For example, Figures 19 and 20 analyse the effect of size. Figure 19 shows the variation in efficiency as a function of the number of modules for a series of possible flow rates. The number of modules is the same as the length of the radiant exchanger. In this case, one module corresponds to a linear tube length of $18 \mathrm{~m}$. These results were calculated for a mean air temperature of $25^{\circ} \mathrm{C}$, mean radiant temperature of $24^{\circ} \mathrm{C}$, and inlet water temperature of $15^{\circ} \mathrm{C}$. The results obtained were as expected. If the water flow is the minimum $\left(2 \frac{1}{\mathrm{~min}}\right)$, the maximum length per $\mathrm{m}^{2}$ of active surface is required to achieve the same efficiency as 
the other cases. This result allows deciding which is the most interesting solution: a low operation cost (pumping cost) or a high initial cost (diameter of tubes). Figure 19 shows the efficiency of $80 \%$ when the water flow is $2 \frac{1}{\mathrm{~min}}$ and the length of the radiant exchanger is $108 \mathrm{~m}$. This length is linked to the surface of the radiant ceiling.

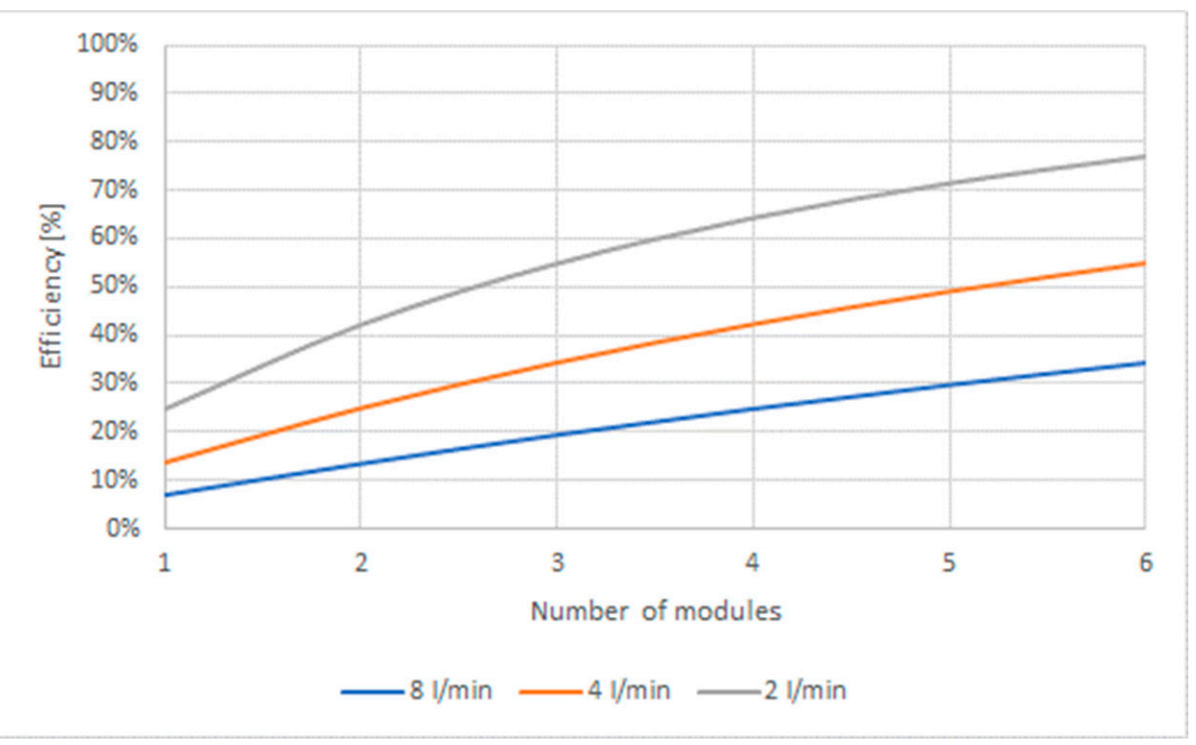

Figure 19. Efficiency vs. number of modules.

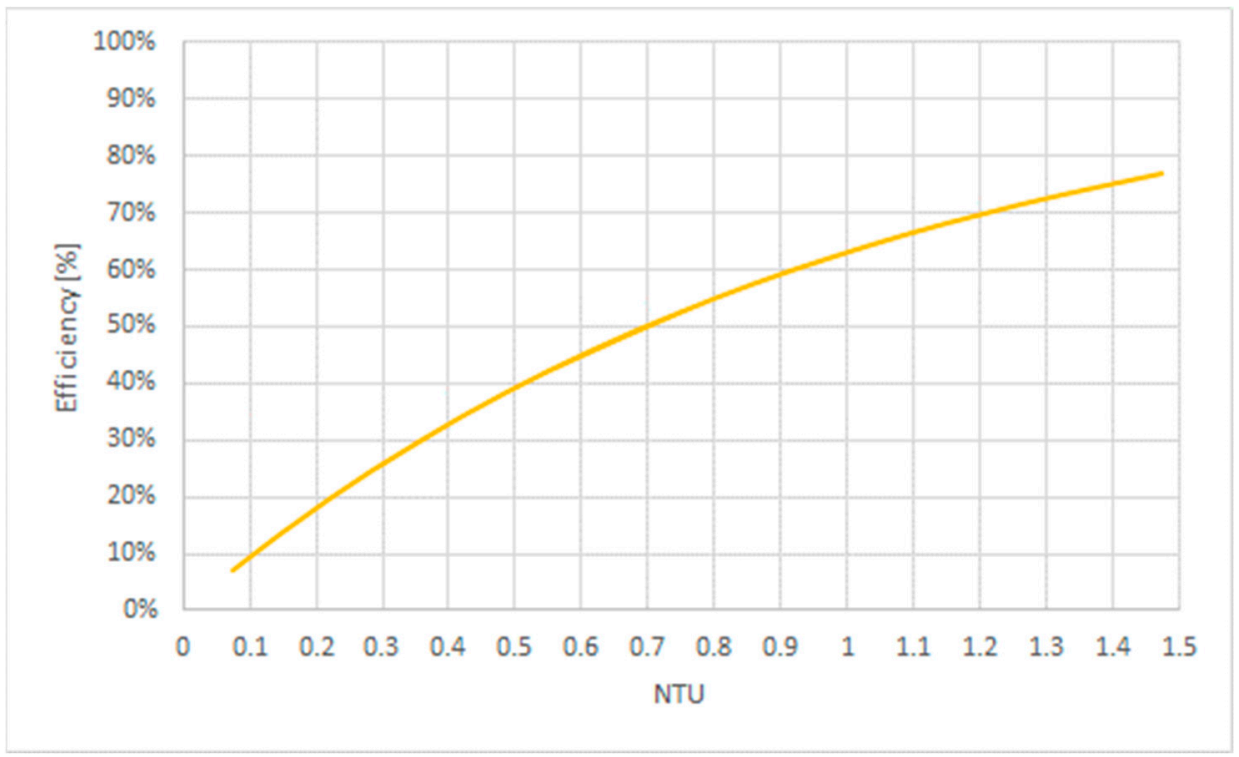

Figure 20. Efficiency vs. NTU.

On the other hand, Figure 20 shows the variation in efficiency as a function of the number of transfer units (NTU).

In the cases of Figure 20, NTU is the combination of active surface and water flow effects. Then, a higher NTU implies a greater linear length of tubes through which a low flow circulates.

In addition to the results before, $\varepsilon-N T U$ procedure allows evaluating the results for a known solution (108 $\mathrm{m}$ of the radiant exchanger and water flow of $\left.2 \frac{1}{\min }\right)$. Figure 21 shows a series of curves of the total absorbed heat flux as a function of the $L M T D_{c v}$ (convective excitation), where each curve refers to a value of $L M T D_{\text {rad }}$ (radiant excitation). 


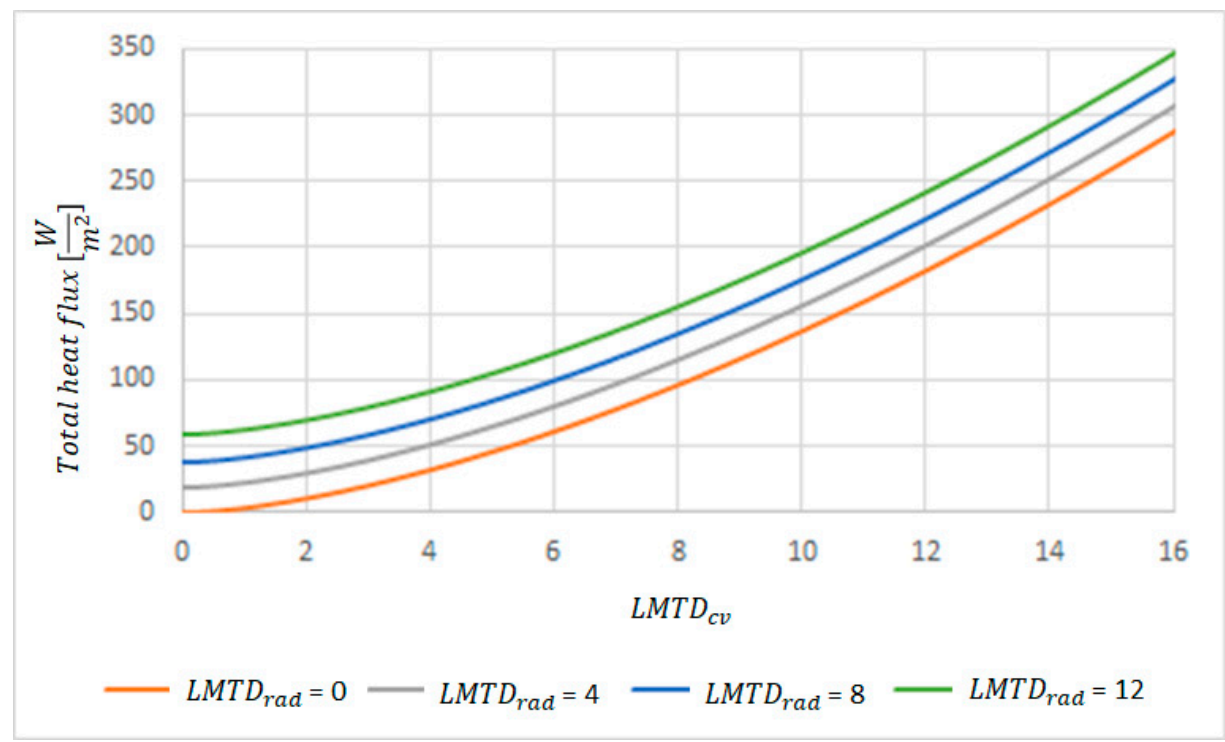

Figure 21. Total heat flux based on different DTLMs.

It is possible to pre-design radiant elements and auxiliary equipment using Figure 21. For example, a certain $L M T D_{\text {Rad }}$ is desired due to the evaluation of any comfort index. However, it is necessary to calculate the total heat flux required to obtain this LMTD. So, Figure 21 facilitates obtaining total heat flux absorbed (cooling) or dissipated (heating) for the water flow in different air temperature conditions. Total heat flux relates to the outlet water temperature and the hot/cold water production system.

\section{Conclusions}

Thermal comfort in open spaces requires implementing different strategies, such as solar protection or cold/heated surfaces. However, it is not easy to get cold/heated surfaces effectively. This study proposes a new concept of radiant solutions adapted for outdoor spaces. It could be used in winter and summer conditions. This conceptual solution is made up of conventional elements integrated into a design adapted to this type of space. The proposed conceptual solution has been described, and its experimentation was carried out to evaluate its behaviour under different design and operation conditions. Also, a simplified model for decision-making issues was developed, which has been validated using experimental results.

The experimental work carried out has allowed for development and evaluation of a radiant solution integrated into open spaces to improve their habitability. Results showed that the radiant effect accounts for $40 \%$ of the system's energy consumption in summer and $60 \%$ in winter. Also, it has shown that it is possible to achieve a homogeneous temperature $\left( \pm 2{ }^{\circ} \mathrm{C}\right)$ on the ceiling's surface by employing the tube exchanger embedded in it.

On the other hand, the experimental facility has allowed thermal characterisation by a simplified model. Validation results confirmed the high quality and precision of its estimations. The developed model allows users to obtain the exchanged heat flow and the return temperature of the water as a function of the environmental conditions surrounding that active surface and the design and operation parameters of that solution. In this way, it is possible to obtain the impact of a modification of the density of embedded tubes on the active surface or a change of operation in the form of flow variation and/ or variation of the water inlet temperature. Validation results tested the reliability and robustness of its estimation. The results obtained with the proposed model in cooling mode presented an average relative error of $2.9 \%$ in regards to the measured heat flux, and the estimation of water outlet presented an average relative error of less than $0.6 \%$, which is why an exhaustive knowledge of it is guaranteed when applying the proposed model. Furthermore, the results obtained in heating mode showed an average relative error lower than that of 
cooling, of only $2.4 \%$ in regards to the measured heat flux. At the same time, the estimation of the water leaving temperature only showed a mean deviation of $0.5 \%$.

Finally, the proposed model allows for the design of the active ceiling through sizing of the surface and definition of the water distribution inside the ceiling. The possibilities of the model have been demonstrated in the developed application. The solution has been integrated into a real space with more than $750 \mathrm{~m}^{2}$ of active ceilings in an open space. Design parameters of the active surface have been selected to achieve the best performance with minimum consumption.

It is necessary to control the radiant temperature of solar protection in open spaces when the aim is climatic control. The experimental results have tested the proposed system's efficiency and have provided knowledge of the convective and radiant effects in detail. In addition, the proposed model provides the thermal response of the solution to variations in its design or operating conditions. So, different examples have been described in the discussion section. Furthermore, this application included the usefulness of the model for decision-making in design phases or even in optimal management of such solutions. Finally, it is possible to design the integration of the radiant system into a new space using the model developed.

Author Contributions: M.G.D.: research, writing, original draft preparation-review and editing. D.C.M.: model, validation, and writing. J.S.R.: validation, conceptualisation, and supervision. T.R.P.A.: data curation and visualisation. S.Á.D.: conceptualisation, methodology, and formal analysis. J.A.T.R.: experimental facility, coordination, and resources. All authors have read and agreed to the published version of the manuscript.

Funding: The European Commission funded this study under the projects UIA03-301-CartujaQanat of Urban Innovative Action (UIA). It has been co-financed by the European Regional Development Funds (ERDF).

Institutional Review Board Statement: Not applicable.

Informed Consent Statement: Not applicable.

Acknowledgments: Israel Ortega (Uponor Iberia) and his team for his support with the experimental prototype.

Conflicts of Interest: The authors declare no conflict of interest.

\section{Abbreviations}

\begin{tabular}{|c|c|}
\hline Variable & Description \\
\hline$m_{w}$ & Water flow \\
\hline$\rho_{w}$ & Water density \\
\hline$C p_{w}$ & Specific heat of water \\
\hline$Q_{c v}$ & Convective heat flux \\
\hline$Q_{\text {rad }}$ & Radiant heat flux \\
\hline$P$ & Total density heat flux \\
\hline$P_{c v}$ & Convective density heat flux \\
\hline$P_{\text {rad }}$ & Radiant density heat flux \\
\hline$h_{c v}$ & Convective heat transfer coefficient \\
\hline$h_{\text {rad }}$ & Radiant heat transfer coefficient \\
\hline$L M T D_{c v}$ & Log mean temperature difference (convective) \\
\hline$L M T D_{\text {rad }}$ & Log mean temperature difference (radiant) \\
\hline$T_{\text {rad }}$ & Radiant mean temperature \\
\hline$S T$ & Surface temperature \\
\hline$f$ & View factor \\
\hline$\varepsilon$ & Emissivity \\
\hline$\sigma$ & Stefan-Boltzmann constant \\
\hline$\overline{T_{w}}$ & Mean water temperature inside the circuit \\
\hline$T_{e q}$ & Equivalent convective radiant temperature \\
\hline
\end{tabular}




$\begin{array}{llc}T_{a} & \text { Mean air temperature } & { }^{\circ} \mathrm{C} \\ T_{\text {water in }} & \text { Inlet water temperature } & { }^{\circ} \mathrm{C} \\ T_{\text {water out }} & \text { Outlet water temperature } & { }^{\circ} \mathrm{C} \\ U & \text { Global heat transfer coefficient } & \frac{\mathrm{W}}{\mathrm{m}^{2} \cdot{ }^{\circ} \mathrm{C}} \\ A & \text { Active surface } & \mathrm{m}^{2} \\ \dot{m}\left(\frac{\mathrm{kg}}{\mathrm{s}}\right) & \text { Operation water flow } & \frac{\mathrm{kg}}{\mathrm{s}} \\ N T U & \text { Number of transfer units } & - \\ \varepsilon & \text { Efficiency } & -\end{array}$

\section{References}

1. Santamouris, M. Cooling the cities-A review of reflective and green roof mitigation technologies to fight heat island and improve comfort in urban environments. Sol. Energy 2014, 103, 682-703. [CrossRef]

2. Santamouris, M. On the energy impact of urban heat island and global warming on buildings. Energy Build. 2014, 82, 100-113. [CrossRef]

3. Höppe, P. Different aspects of assessing indoor and outdoor thermal comfort. Energy Build. 2002, 34, 661-665. [CrossRef]

4. Cordero, X. Microclima y Confort Térmico Urbano: Análisis Sobre la Influencia de la Morfología del Cañón Urbano Caso de Estudio en Los Barrios el Raval y Gracia, Barcelona. Master's Thesis, Universitat Politècnica de Catalunya, Barcelona, Spain, 2014; p. 110.

5. Pinto, D.; Rocha, A.; Simões, M.L.; Almeida, R.M.S.F.; Barreira, E.; Pereira, P.F.; Ramos, N.M.M.; Poças Martins, J. An innovative approach to evaluate local thermal discomfort due to draught in semi-outdoor spaces. Energy Build. 2019, 203, 109416. [CrossRef]

6. Sarhadi, F.; Rad, V.B. The structural model for thermal comfort based on perceptions individuals in open urban spaces. Build. Environ. 2020, 185, 107260. [CrossRef]

7. Liu, W.; Zhang, Y.; Deng, Q. The effects of urban microclimate on outdoor thermal sensation and neutral temperature in hot-summer and cold-winter climate. Energy Build. 2016, 128, 190-197. [CrossRef]

8. Lai, D.; Lian, Z.; Liu, W.; Guo, C.; Liu, W.; Liu, K.; Chen, Q. A comprehensive review of thermal comfort studies in urban open spaces. Sci. Total Environ. 2020, 742, 140092. [CrossRef] [PubMed]

9. Wang, Y.; Lian, Z.; Broede, P.; Lan, L. A time-dependent model evaluating draft in indoor environment. Energy Build. 2012, 49, 466-470. [CrossRef]

10. Zhang, Y.; Liu, J.; Zheng, Z.; Fang, Z.; Zhang, X.; Gao, Y.; Xie, Y. Analysis of thermal comfort during movement in a semi-open transition space. Energy Build. 2020, 225, 110312. [CrossRef]

11. Velazquez, R.; Alvarez, S.; Guerra, J. Climatic control of outdoor spaces in EXPO'92. Sun Work Eur. 1992, 7, 3-10.

12. Givoni, B. Climate Considerations in Building and Urban Design; John Wiley \& Sons: New York, NY, USA, 1998; pp. 241-300.

13. Zhang, F.; Guo, H.A.; Liu, Z.; Zhang, G. A critical review of the research about radiant cooling systems in China. Energy Build. 2021, 235, 110756. [CrossRef]

14. Rocha, A.; Pinto, D.; Ramos, N.M.M.; Almeida, R.M.S.F.; Barreira, E.; Simões, M.L.; Martins, J.P.; Pereira, P.F.; Sanhudo, L. A case study to improve the winter thermal comfort of an existing bus station. J. Build. Eng. 2020, 29, 101123. [CrossRef]

15. Wang, Y.; Bakker, F.; de Groot, R.; Wörtche, H.; Leemans, R. Effects of urban green infrastructure (UGI) on local outdoor microclimate during the growing season. Environ. Monit. Assess. 2015, 187, 1-14. [CrossRef]

16. Wang, Y.; Akbari, H. The effects of street tree planting on Urban Heat Island mitigation in Montreal. Sustain. Cities Soc. 2016, 27, 122-128. [CrossRef]

17. Abdallah, A.S.H.; Hussein, S.W.; Nayel, M. The impact of outdoor shading strategies on student thermal comfort in open spaces between education building. Sustain. Cities Soc. 2020, 58, 102124. [CrossRef]

18. Rossi, F.; Cardinali, M.; Gambelli, A.M.; Filipponi, M.; Castellani, B.; Nicolini, A. Outdoor thermal comfort improvements due to innovative solar awning solutions: An experimental campaign. Energy Build. 2020, 225, 110341. [CrossRef]

19. Ferrari, A.; Kubilay, A.; Derome, D.; Carmeliet, J. The use of permeable and reflective pavements as a potential strategy for urban heat island mitigation. Urban Clim. 2020, 31, 100534. [CrossRef]

20. Kyriakodis, G.E.; Santamouris, M. Using reflective pavements to mitigate urban heat island in warm climates-Results from a large scale urban mitigation project. Urban Clim. 2016, 24, 326-339. [CrossRef]

21. Bianco, L.; Serra, V.; Larcher, F.; Perino, M. Thermal behaviour assessment of a novel vertical greenery module system: First results of a long-term monitoring campaign in an outdoor test cell. Energy Effic. 2017, 10, 625-638. [CrossRef]

22. Kolokotsa, D.D.; Giannariakis, G.; Gobakis, K.; Giannarakis, G.; Synnefa, A.; Santamouris, M. Cool roofs and cool pavements application in Acharnes, Greece. Sustain. Cities Soc. 2018, 37, 466-474. [CrossRef]

23. Guerrero Delgado, M.; Sánchez Ramos, J.; Pavón Moreno, M.; Tenorio Ríos, J.A.; Álvarez Domínguez, S. Experimental analysis of atmospheric heat sinks as heat dissipators. Energy Convers. Manag. 2020, 207, 112550. [CrossRef]

24. Guerrero Delgado, M.; Sánchez Ramos, J.; Álvarez Domínguez, S.; Toral Ulloa, F.; Tenorio Ríos, J.A. Evaporative Mist Cooling as Heat Dissipation Technique: Experimental Assessment and Modelling. Appl. Sci. 2020, 10, 6026. [CrossRef]

25. Guerrero, M.; Sánchez, J.; Antonio, J.; Ríos, T. Falling-film as natural cooling technique: Modelling and energy impact assessment. Energy Convers. Manag. 2020, 221, 113168. [CrossRef] 
26. Xie, Y.; Huang, T.; Li, J.; Liu, J.; Niu, J.; Mak, C.M.; Lin, Z. Evaluation of a multi-nodal thermal regulation model for assessment of outdoor thermal comfort: Sensitivity to wind speed and solar radiation. Build. Environ. 2018, 132, 45-56. [CrossRef]

27. Zhang, H.; Yang, X.; Zheng, W.; You, S.; Zheng, X.; Ye, T. The CPMV* for assessing indoor thermal comfort and thermal acceptability under global solar radiation in transparent envelope buildings. Energy Build. 2020, 225, 110306. [CrossRef]

28. Andrés-Chicote, M.; Tejero-González, A.; Velasco-Gómez, E.; Rey-Martínez, F.J. Experimental study on the cooling capacity of a radiant cooled ceiling system. Energy Build. 2012, 54, 207-214. [CrossRef]

29. Zhao, W.; Kilpeläinen, S.; Kosonen, R.; Jokisalo, J.; Lestinen, S.; Wu, Y.; Mustakallio, P. Human response to thermal environment and perceived air quality in an office with individually controlled convective and radiant cooling systems. Build. Environ. 2021, 195. [CrossRef]

30. Bogatu, D.-I.; Kazanci, O.B.; Olesen, B.W. An Experimental Study of the Active Cooling Performance of a Novel Radiant Ceiling Panel Containing Phase Change Material (PCM). Energy Build. 2021, 243, 110981. [CrossRef]

31. Tang, H.; Zhang, T.; Liu, X.H.; Li, C. A novel pulse width modulation for metal radiant panels to control the condensation risk in a hot and humid environment. Build. Environ. 2021, 196, 107802. [CrossRef]

32. Shen, C.; Li, X. Dynamic thermal performance of pipe-embedded building envelope utilizing evaporative cooling water in the cooling season. Appl. Therm. Eng. 2016, 106, 1103-1113. [CrossRef]

33. Radwan, A.; Katsura, T.; Ding, L.; Serageldin, A.A.; EL-Seesy, A.I.; Nagano, K. Design and thermal analysis of a new multisegmented mini channel based radiant ceiling cooling panel. J. Build. Eng. 2021, 40, 102330. [CrossRef]

34. Sharma, H.B.; Panigrahi, S.; Sarmah, A.K.; Dubey, B.K. Numerical investigation of the thermal performance of a radiant ceiling cooling panel with segmented concave surfaces. J. Build. Eng. 2021, 42, 102450. [CrossRef]

35. Ning, B.; Chen, Y. A radiant and convective time series method for cooling load calculation of radiant ceiling panel system. Build. Environ. 2021, 188, 107411. [CrossRef]

36. Incropera, F.P. Fundamentals of Heat and Mass Transfer; John Wiley \& Sons: New York, NY, USA, 2011; Volume 16, ISBN 9780471457282.

37. Bergman, T.L.; Incropera, F.P. Fundamentals of Heat and Mass Transfer, 8th ed.; John Wiley \& Sons: New York, NY, USA, 2011; ISBN 0470501979.

38. EES: Engineering Equation Solver; Engineering Software; F-Chart Software: Madison, WI, USA, 2020.

39. Doulos, L.; Santamouris, M.; Livada, I. Passive cooling of outdoor urban spaces. The role of materials. Sol. Energy 2004, 77, 231-249. [CrossRef]

40. Santamouris, M.; Kolokotsa, D. Urban Climate Mitigation Techniques; Routledge: London, UK, 2016; ISBN 978-0415712132.

41. Mansour, M.K. Practical effectiveness-NTU model for cooling and dehumidifying coil with non-unit Lewis Factor. Appl. Therm. Eng. 2016, 100, 1111-1118. [CrossRef]

42. Çengel, Y.A.; Ghajar, A.J. Heat and Mass Transfer, 5th ed.; McGraw-Hill Higher Education: New York, NY, USA, 2015. 